\title{
Implications of accounting for land use in simulations of ecosystem carbon cycling in Africa
}

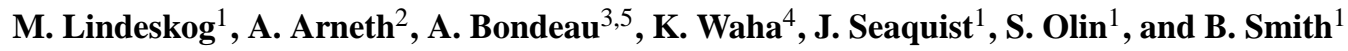 \\ ${ }^{1}$ Department of Physical Geography and Ecosystem Science, Lund University, Sölvegatan 12, 22362 Lund, Sweden \\ ${ }^{2}$ Karlsruhe Institute of Technology, Institute of Meteorology and Climate Research - Atmospheric Environmental Research \\ (IMK-IFU), Kreuzeckbahnstr. 19, 82467 Garmisch-Partenkirchen, Germany \\ ${ }^{3}$ Climate Impacts and Vulnerabilities, Potsdam Institute for Climate Impact Research (PIK), P.O. Box 60 1203, \\ 14412 Potsdam, Germany \\ ${ }^{4}$ Earth System Analysis, Potsdam Institute for Climate Impact Research (PIK), P.O. Box 60 1203, 14412 Potsdam, Germany \\ ${ }^{5}$ Mediterranean Institute of Biodiversity and Ecology (IMBE), CNRS/Aix-Marseille University/IRD/UAPV, \\ Bâtiment Villemin, Europole de l'Arbois, BP 80, 13545 Aix-en-Provence cedex 04, France
}

Correspondence to: M. Lindeskog (mats.lindeskog@nateko.lu.se)

Received: 5 November 2012 - Published in Earth Syst. Dynam. Discuss.: 7 February 2013

Revised: 20 September 2013 - Accepted: 3 October 2013 - Published: 1 November 2013

\begin{abstract}
Dynamic global vegetation models (DGVMs) are important tools for modelling impacts of global change on ecosystem services. However, most models do not take full account of human land management and land use and land cover changes (LULCCs). We integrated croplands and pasture and their management and natural vegetation recovery and succession following cropland abandonment into the LPJ-GUESS DGVM. The revised model was applied to Africa as a case study to investigate the implications of accounting for land use on net ecosystem carbon balance (NECB) and the skill of the model in describing agricultural production and reproducing trends and patterns in vegetation structure and function. The seasonality of modelled monthly fraction of absorbed photosynthetically active radiation (FPAR) was shown to agree well with satellite-inferred normalised difference vegetation index (NDVI). In regions with a large proportion of cropland, the managed land addition improved the FPAR vs. NDVI fit significantly. Modelled 1991-1995 average yields for the seven most important African crops, representing potential optimal yields limited only by climate forcings, were generally higher than reported FAO yields by a factor of 2-6, similar to previous yield gap estimates. Modelled inter-annual yield variations during 1971-2005 generally agreed well with FAO statistics, especially in regions with pronounced climate seasonality. Modelled land-atmosphere carbon fluxes for Africa
\end{abstract}

associated with land use change $\left(0.07 \mathrm{PgC} \mathrm{yr}^{-1}\right.$ release to the atmosphere for the 1980s) agreed well with previous estimates. Cropland management options (residue removal, grass as cover crop) were shown to be important to the landatmosphere carbon flux for the 20th century.

\section{Introduction}

A large part of the earth's ice-free surface is covered by managed land, e.g. croplands (about $11 \%$ ) and pasture (about $24 \%$ ) (Klein Goldewijk et al., 2011). Increased demand for food, fibre and energy production by a growing human population is responsible for an expansion of managed land into intact natural vegetation and more intensive management of existing managed land. This is often in conflict with the goal of preserving global biodiversity (Heywood, 1995). Anthropogenic land use and land cover changes (LULCCs) have been important contributors to rising atmospheric $\mathrm{CO}_{2}$ concentrations (hereinafter " $\mathrm{CO}_{2}$ ") in the past, accounting for an estimated $156 \mathrm{PgC}$ released for the period 1850-2000 (Houghton, 2003). Land use, particularly tropical deforestation, continues to contribute significantly to anthropogenic greenhouse gas emissions, releasing an average of around $2 \mathrm{PgC} \mathrm{yr}^{-1}$ for the 1980s and 1990s (Houghton, 2003; Le Quéré et al., 2009; Zaehle et al., 2011). LULCC may also 
lead to changes in land surface properties and near-surface energy, water and momentum exchange, contributing to biophysical climate forcing (Pitman et al., 2009; Wramneby et al., 2010; Arora and Montenegro, 2011).

Climate change is predicted to cause adverse effects on terrestrial vegetation in large parts of the world, putting further stress on both biodiversity and managed land productivity (Foley et al., 2005). Combined effects of rising $\mathrm{CO}_{2}$, climate change and LULCC will act to influence the role of the terrestrial biosphere in the global carbon budget by altering net primary productivity (NPP) and soil carbon turnover, altering the potential of soil and vegetation to store carbon (McGuire et al., 2001).

Agricultural production of food and fodder is one of the key ecosystem services underpinning the well-being and development of human society (Millennium Ecosystem Assessment, 2005). Increasing temperatures are projected to have negative consequences for crop yields in many regions, especially in the lower latitudes that already experience warm temperatures (Easterling et al., 2007). Changes in precipitation will be more variable regionally and might exacerbate or alleviate the negative effects of raised temperatures, depending on the sign of change (Roudier et al., 2011). Furthermore, an increase in climate variability leading to stronger and more frequent extreme events, such as droughts and floods, may generally be expected to cause a reduction of crop yields (Rowhani et al., 2011). A $\mathrm{CO}_{2}$ fertilisation effect may reduce the negative effects of raised temperatures on crop production, but the overall magnitude and persistence of such an effect is still debated (Ainsworth and Long, 2005; Long et al., 2006; Tubiello et al., 2007; Müller et al., 2009). A certain degree of adaptation to climate change may be possible through an appropriate choice of cropping systems (Waha et al., 2013).

Africa has been identified as one of the world's most vulnerable regions to climate change (Müller et al., 2011). Projected decreasing crop yields combined with a rapid population increase make food shortage a likely scenario (Müller et al., 2009), but the pattern is regionally complex. A review of both empirical and processed-based crop models on future yields in West Africa shows a high degree of agreement on the negative crop yield prospects (Roudier et al., 2011). In East Africa, precipitation is predicted to increase in the future according to projections from a majority of general circulation models (GCMs). A resulting possible increase in NPP may also lead to increased crop yields (Doherty et al., 2010).

The African continent has been acting as a carbon sink for most of the 20th century, sequestering carbon mainly into forest biomass (Ciais et al., 2009). Intact African tropical forests stored $0.34 \mathrm{PgC} \mathrm{yr}^{-1}$ during the past $40 \mathrm{yr}$ (Lewis et al., 2009) while in the absence of fire, $\mathrm{CO}_{2}$ uptake in African savannahs has been estimated at $1.9 \mathrm{PgC} \mathrm{yr}^{-1}$ (Bombelli et al., 2009). Savannah fires, either as natural episodic events or resulting from human management, release much of this carbon back to the atmosphere (van der Werf et al., 2008;
Lehsten et al., 2009). LULCC, such as the conversion of forest into cropland or pasture, releases large amounts of $\mathrm{CO}_{2}$ and also reduces the carbon sink potential. The present-day African deforestation-related carbon loss has been estimated at $0.4 \mathrm{PgC} \mathrm{yr}^{-1}$ (Williams et al., 2007), which is relatively modest compared with other tropical forest regions, mainly because of lower deforestation rates. Conversely, abandonment of cropland and the subsequent succession into forest sequesters atmospheric $\mathrm{CO}_{2}$, especially during early successional phases (Houghton et al., 1983). Improved knowledge of carbon fluxes related to deforestation, afforestation, and crop and pasture processes may provide important information to help determine the preferred land management options for an area with respect to carbon sequestration.

Dynamic global vegetation models (DGVMs) have been used for modelling terrestrial vegetation dynamics and ecosystem biogeochemistry under changing climate and $\mathrm{CO}_{2}$, and have been widely used to investigate the potential for terrestrial biota to feed back to climate change, particularly through carbon cycle changes (McGuire et al., 2001; Friend et al., 2007; Sitch et al., 2008; Arneth et al., 2010a,b). At first DGVMs accounted for LULCC by simulating grassland instead of natural forest or by harvesting a fraction of the natural NPP (McGuire et al., 2001; Brovkin et al., 2004). However, the large variety of crop management practices worldwide made an implementation of specific crop or pasture functions (phenology, carbon allocation and overall productivity) within DGVMs desirable. Several DGVMs now have the capabilities of accounting for both natural vegetation and agriculture (crops and/or pasture), either at the scale of a large region (Kucharik and Brye, 2003; de Noblet-Ducoudré et al., 2004; Gervois et al., 2004; Kucharik and Twine, 2007; Van den Hoof et al., 2011; Berg et al., 2011; Hidy et al., 2012) or globally (Bondeau et al., 2007; Müller et al., 2007).

To evaluate the importance of croplands and pasture for land-atmosphere coupling and the carbon cycle, we integrated managed land and LULCC functionality into a DGVM optimised for regional applications, further developing an approach adopted from Bondeau et al. (2007). Focusing on Africa as a case study, we simulated crop production, seasonal and interannual variability of vegetation productivity and the continental-scale land-atmosphere carbon fluxes forced by recent historical climate, $\mathrm{CO}_{2}$ and observed land use and land cover. We evaluate the skill of the model in comparison to observations and investigate how the introduction of managed land affects the predictions of the model across the climate space of Africa. 


\section{Methods}

\subsection{DGVM}

We employed LPJ-GUESS (Lund-Potsdam-Jena General Ecosystem Simulator, Smith et al., 2001), a DGVM optimised for regional applications, as the modelling platform for our study. LPJ-GUESS combines a detailed, individualand patch-based representation of vegetation structure, demography and resource competition with physiological and biogeochemical process formulations in common with the more generalised global model LPJ-DGVM as detailed by Sitch et al. (2003) with modifications by Gerten et al. (2004). The model was applied on a $0.5^{\circ} \times 0.5^{\circ}$ regular latitudelongitude grid across Africa at a daily time step. The potential natural vegetation in each grid cell was simulated as a dynamic mixture of up to six tree and two grass plant functional types (PFTs), using the PFT set and parameters described in Ahlström et al. (2012a). Photosynthesis, respiration and water uptake are modelled at a daily time step, and tissue turnover and carbon allocation to leaves, fine roots and stems (sapwood) are modelled at a yearly time step, independently for each tree, or generically for $\mathrm{C}_{3}$ and $\mathrm{C}_{4}$ grasses, respectively, in each of a number (20 in this study) of replicate patches accommodating variation of vegetation dynamics within the potential natural vegetation fraction of each simulated grid cell. Height and diameter growth of trees are regulated by carbon allocation, sapwood-to-heartwood conversion, and a set of prescribed allometric relationships for each PFT. Population dynamics (establishment and mortality; yearly time step) are influenced by current availability and uptake of light and soil water, stand size structure, and the life history characteristics of each PFT (Hickler et al., 2004). Biomass-destroying disturbances are simulated as a stochastic process, here with a generic expectation of $0.01 \mathrm{yr}^{-1}$. In addition, fires are modelled prognostically based on temperature, current fuel load and moisture (Thonicke et al., 2001). A detailed description of LPJ-GUESS is given by Smith et al. (2001).

LPJ-GUESS has been evaluated extensively and exhibits comparable skill to other approaches and models in reproducing observed temporal and spatial variation in large-scale vegetation patterns, productivity and ecosystem-atmosphere carbon exchange (Piao et al., 2013). Results from the model have been compared to ecosystem flux measurements, site measurements and satellite-based proxies of NPP, leaf area index (LAI) and biomass, spanning many of the world's biomes (Morales et al., 2005; Hickler et al., 2005, 2006; Hély et al., 2006; Smith et al., 2008; Ahlström et al., 2012a). LPJ-GUESS has been shown to be better than LPJ-DGVM at predicting potential natural vegetation, e.g. in Europe and Africa (Smith et al., 2001; Hély et al., 2006; Hickler et al., 2012). Also, African vegetation-atmosphere carbon balance responds differently to climate drivers using LPJ-GUESS compared to LPJ-DGVM (Weber et al., 2009).
Table 1. PFT growing season parameters for crop PFTs used in this study.

\begin{tabular}{lccr}
\hline Crop PFT & $T_{\text {sow }}$ & $T_{\mathrm{b}}$ & PHU range \\
\hline Temperate cereals & $5 / 12$ & 0 & $900-5184(2640)$ \\
Rapeseed & $5 / 17$ & 0 & $2054-5646(4027)$ \\
Maize & 14 & $\mathbf{8}$ & $900-4251(2997)$ \\
Pulses & 10 & 3 & $900-6256(3959)$ \\
Sugar beet & 8 & 3 & $900-5598(3630)$ \\
Rice & 18 & 10 & $900-3761(2817)$ \\
Soybean & 13 & 10 & $900-3303(2198)$ \\
Sunflower & 15 & 6 & $900-3854(2786)$ \\
Tropical cereals & 12 & 10 & $900-4709(2670)$ \\
Peanut & 15 & 14 & $900-2711(1788)$ \\
Cassava & 22 & $\mathbf{1 5}$ & $900-2903(1758)$ \\
\hline
\end{tabular}

* Temperate cereals: wheat, barley, rye, oat; tropical cereals: millet, sorghum; $T_{\text {sow }}$ : temperature limit used for crop sowing. For temperate cereals and rapeseed, the values are for spring/autumn sowing; $T_{\mathrm{b}}$ : HU base temperature. Values are from Bondeau et al. (2007) or Waha et al. (2012) except for values in bold type, where the $T_{\mathrm{b}}$ values are more common values found in the literature; PHU range used in this study with mean in brackets.

Land use and cropland representations were implemented in LPJ-GUESS based on LPJ-mL, which is derived from LPJ-DGVM (Bondeau et al., 2007), with a number of modifications (see below). Cropland is represented by 11 crop PFTs (Table 1), simulated separately (without inter-PFT competition) and two grass PFTs ( $\mathrm{C}_{3}$ and $\mathrm{C}_{4}$ grass) as cover crop between harvest and sowing. The same grass PFTs are used to represent pastures. Irrigated crops are simulated separately. For temperate cereals, an upper temperature limit of $15^{\circ} \mathrm{C}$ for the coldest month for growth is set to avoid their parameterization in tropical climates, following Bondeau et al. (2007). The main modifications in the model compared to LPJ-mL as described by Bondeau et al. (2007) are a new phenology scheme, coupling LAI and leaf $\mathrm{C}$ mass on a daily time step, a dynamic potential heat unit (PHU) calculation based on local climate conditions in each grid cell, simulation of regeneration and recovery of vegetation by creating a new natural vegetation stand following cropland abandonment and a revised calculation of crop sowing dates following Waha et al. (2012). Crop irrigation is treated differently in LPJ-GUESS compared to LPJ-mL. Irrigation water is added if atmospheric demand for transpiration exceeds plant water supply, but irrigated crops can still enter water stress if atmospheric demand exceeds a maximum evapotranspiration rate $\left(5 \mathrm{~mm} \mathrm{day}^{-1}\right)$. Also, pasture grass and cover crop grass is simulated by competing $\mathrm{C}_{3}$ and $\mathrm{C}_{4}$ grass, while in LPJ-mL, $\mathrm{C}_{3}$ and $\mathrm{C}_{4}$ grasses were grown in separate stands, according to a static $\mathrm{C}_{3} / \mathrm{C}_{4}$ ratio for each grid cell.

In LPJ-mL, crop phenology followed the development of the potential LAI, which was coupled to the sum of heat units (degree days above a crop-specific base temperature, $T_{\mathrm{b}}$ ) accumulated from the time of sowing, and eventually corrected if a climatic stress reduced the actual available carbon for 


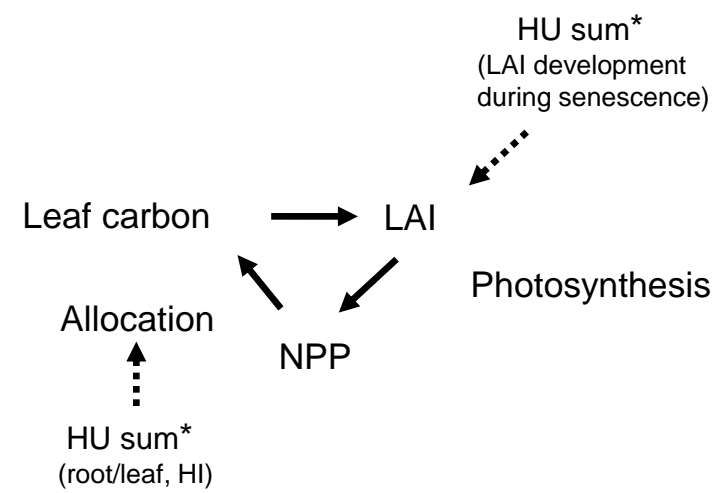

Fig. 1. Crop phenology in LPJ-GUESS. The feedback between leaf area and leaf carbon mass via NPP is denoted by full-line arrows and the heat unit sum control of the carbon allocation and LAI is denoted by dotted arrows. ${ }^{*}$ HU sum: heat unit sum (dynamic potential HU adapted to local climate); LAI: leaf area index; HI: harvest index; NPP: net primary production.

leaf growth (Bondeau et al., 2007). This could cause significant discrepancies between daily values of heat sum-based LAI and actual available carbon for leaf growth based on the simulated leaf carbon assimilation. This method also requires a fixed maximum LAI value that is dependent on management, but that does not respond to a changing environment (e.g. changing $\mathrm{CO}_{2}$ ). In LPJ-GUESS, we introduced instead a feedback between daily leaf carbon mass and LAI, making the leaf development, before flowering and the onset of senescence, more consistent with physiological constraints (Fig. 1).

Upon sowing, the initial carbon is set to $10 \mathrm{~g} \mathrm{~m}^{-2}$. Carbon allocation to crop roots, leaves and harvestable organs is done at a daily time step. The development of the harvest index (HI, i.e. the fraction of above-ground carbon present in the harvestable organs), the root/shoot ratio and the onset of senescence and LAI development during senescence is dependent on accumulated heat units and calculated as in Bondeau et al. (2007). In LPJ-GUESS, the PHU sum needed for full development of a crop, determining the time at which the crop is harvested, is calculated dynamically, using a $10 \mathrm{yr}$ running mean of heat unit sums accumulated from the sowing date to the end of a sampling period (ranging from 190 to 245 days) derived from default sowing and harvest limit dates as reported by Bondeau et al. (2007). The dynamic PHU calculation can be done either for an initial time period only, to calibrate for the local climate, or also for an extended period, to simulate adaptation to a changing climate by selecting suitable crop varieties/genotypes. In this study, dynamic PHU is used for the whole time period (Table 1). A lower PHU limit of $900^{\circ}$ days was used. Maintenance respiration of storage organs is set to zero. The modelled crop yield represents potential optimal yield, limited by climate and $\mathrm{CO}_{2}$ only.

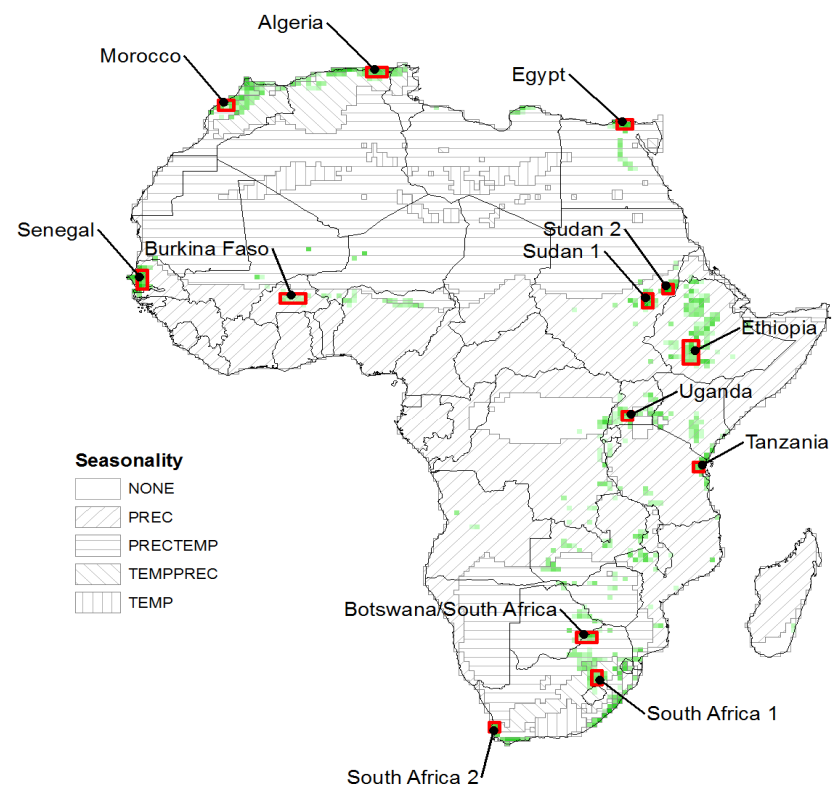

Fig. 2. Location of selected cropland areas. Cells with cropland fractions $>25 \%$ are indicated in green. The climate seasonality types for 1990 used for sowing date calculation by LPJ-GUESS are indicated by hatched grey. The two Sudan crop regions are treated as a single region in the text. The seasonality types are defined in the Methods section.

The relative degree of limitation by temperature and precipitation to the sowing dates - or the absence of such limitation in perennially moist areas (where incoming solar radiation generally limits plant production) - was determined based on the local climatology (Waha et al., 2012) (Fig. 2). Five main seasonality types to determine sowing date were specified as follows: TEMP (temperature seasonality); PREC (precipitation seasonality); TEMPPREC (both temperature and precipitation seasonality, minimum monthly temperature $<10^{\circ} \mathrm{C}$ ), temperature determines sowing date; PRECTEMP (both temperature and precipitation seasonality, minimum monthly temperature $>=10^{\circ} \mathrm{C}$ ), precipitation determines sowing date; NONE (neither temperature nor precipitation seasonality), default sowing date used. For irrigated crops at PRECTEMP sites, temperature-dependent sowing was used unless specifically stated in the text. The temperature limits for temperature-dependent sowing were as in Waha et al. (2011) (Table 1).

Croplands were harvested each year (see Table 2 for harvest parameters used in this study). A PFT-specific fraction of the harvestable organs (the harvest efficiency, set to 0.9 for all crops in this study) constitutes the yield (multiplied by 2.0 for deriving the total dry yield from carbon units, assuming a dry matter carbon content of $50 \%$ ) and is assumed to be oxidised within a year. Of the leaf carbon, a further fraction (the residue removal fraction) is removed (and oxidised within one year). This PFT parameter is set to 0.75 for all crops in this study unless specified otherwise. Grazing 
A
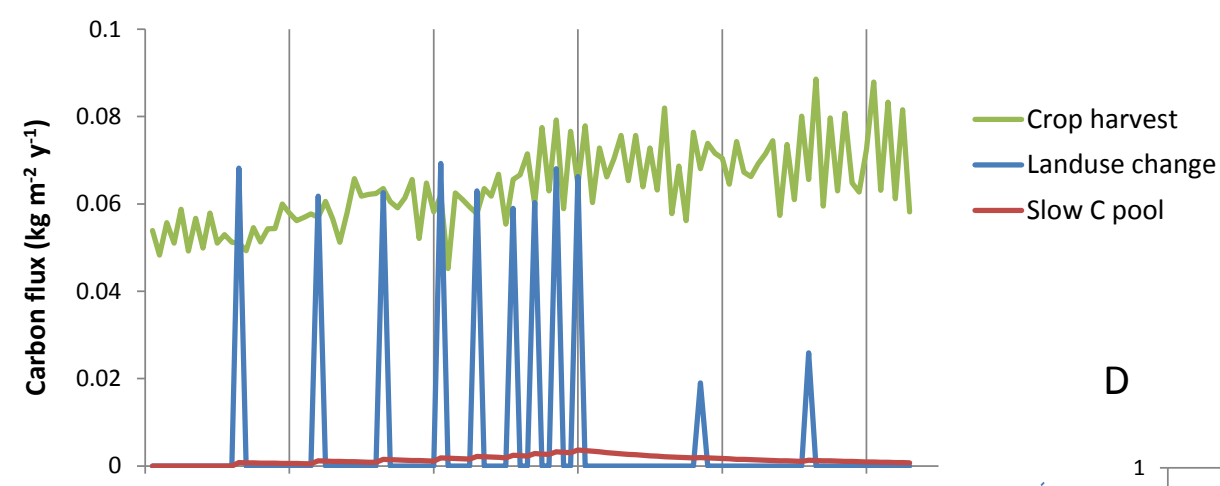

B
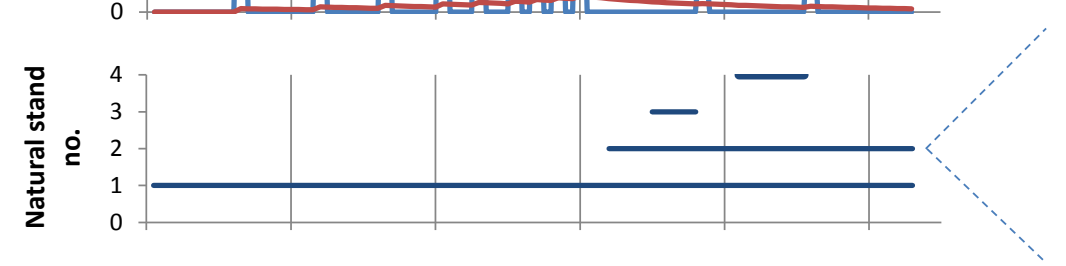

C
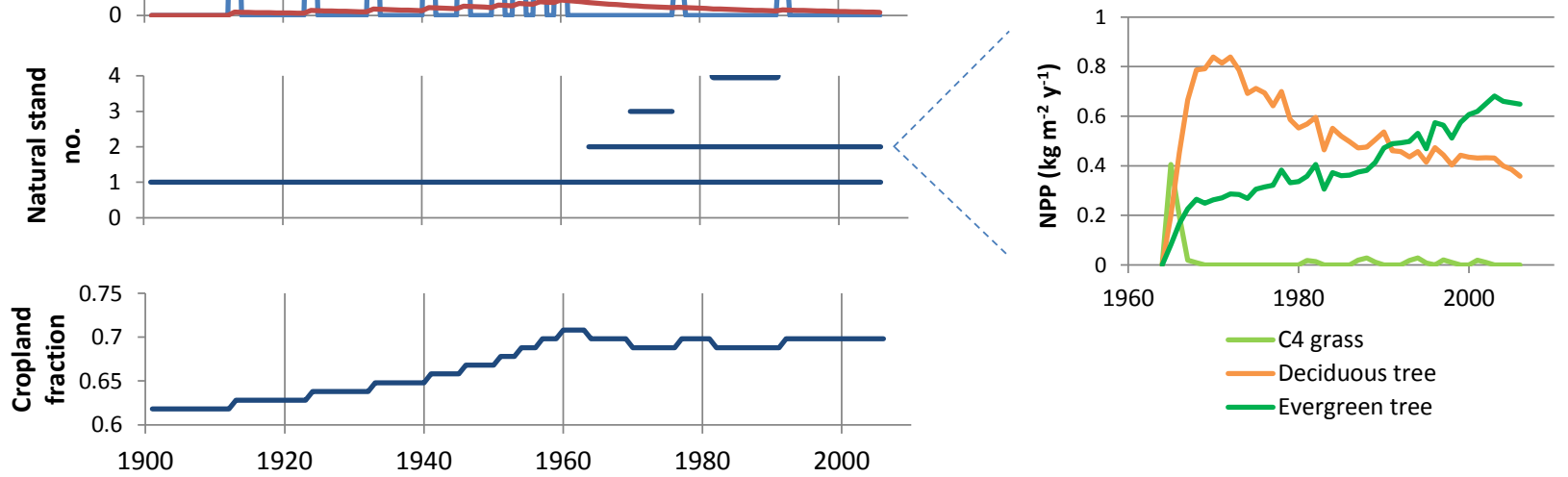

Fig. 3. Example of land use change modelling at a moist tropical site $\left(9^{\circ} \mathrm{W}, 5.5^{\circ} \mathrm{N}\right)$ during the period $1901-2006$ using the Ramankutty and Foley (1999) land cover data set. (A) Carbon fluxes to the atmosphere associated with crop harvest and land use change (cropland expansion/deforestation). The "slow C pool" represents the oxidation of carbon from the long-lived wood pool harvested at cropland expansion. (B) Lifetime of natural vegetation stands. New stands are created at cropland abandonment and destroyed at subsequent cropland expansion. (C) Cropland area fraction, showing the expansion and reduction of cropland area. (D) NPP of three PFTs at one of the natural stands created at cropland abandonment, representing a typical plant successional sequence where an initial dominance of grass is followed by forest, dominated first by deciduous and later by evergreen trees.

Table 2. LPJ-GUESS PFT harvest parameter values used in this study.

\begin{tabular}{|c|c|c|c|c|c|}
\hline $\begin{array}{l}\text { PFT } \\
\text { class }\end{array}$ & $\begin{array}{l}\text { Harvest } \\
\text { efficiency }\end{array}$ & $\begin{array}{l}\text { Harvested } \\
\text { parts }\end{array}$ & $\begin{array}{l}\text { Harvest } \\
\text { slow } \\
\text { fraction }\end{array}$ & $\begin{array}{c}\text { Slow } \\
\text { fraction } \\
\text { turnover } \\
\text { rate } \\
\left(\mathrm{yr}^{-1}\right)\end{array}$ & $\begin{array}{l}\text { Residue } \\
\text { removal }\end{array}$ \\
\hline Trees & 0.7 & wood & 0.33 & 0.04 & 1.0 \\
\hline Grass & 0.5 & leaves & 0 & - & $1.0^{*}$ \\
\hline Crops & 0.9 & storage & 0 & - & 0.75 \\
\hline
\end{tabular}

* natural grass 1.0, pasture and cover crop grass 0.0.

of managed grassland is simulated by removing $50 \%$ of the above-ground carbon. This is roughly in agreement with estimates of a $90 \%$ removal in intensively grazed pastures and a $50 \%$ re-entering of this carbon back to the litter pool as manure. Fires were excluded from pasture and cropland.

At the conversion of forest to cropland, $70 \%$ of tree stems are harvested and the rest is oxidised the same year (burned). Part of the harvested wood (firewood) is oxidised the same year $(67 \%)$ and the rest moved to a pool with a $25-\mathrm{yr}$ turnover period, representing paper and timber. This is a simplified version of Houghton et al. (1983), where two longlived pools $(10 \mathrm{yr} / 100 \mathrm{yr}$ turnover times) exist, also used by McGuire et al. (2001) with LPJ. At cropland abandonment (conversion to natural vegetation), a new stand is created from bare ground, allowing the establishment of natural vegetation with a succession (e.g. from grass to deciduous trees and finally evergreen trees). An example of modelled carbon fluxes at cropland expansion and abandonment is shown for a moist tropical site in Liberia in Fig. 3.

"Land use functionality" in this paper refers to the dynamic representations of different land cover types with associated land uses, in this study specifically irrigated or rain-fed cropland and pasture. The expected difference in, for example, modelled carbon fluxes in simulations with and without land use functionality would be the differential response by different land covers to changes in climate and $\mathrm{CO}_{2}$ as well as the effects of LULCC.

\subsection{Observational data}

Soil texture data were as described by Sitch et al. (2003), and historical yearly global atmospheric $\mathrm{CO}_{2}$ concentrations 
were obtained from the Carbon Cycle Model Linkage project (McGuire et al., 2001). Monthly values of temperature, precipitation and cloudiness were taken from the CRU (Climate Research Unit, University of East Anglia, UK) TS 3.0 data set at $0.5^{\circ}$ resolution (Mitchell and Jones, 2005), provided by the British Atmospheric Data Centre (BADC), National Centre for Atmospheric Science, Natural Environment Research Council( http://badc.nerc.ac.uk/view/badc.nerc.ac. uk_ATOMdataent_1256223773328276). The monthly CRU precipitation data were converted to daily values using a stochastic rain-day generator considering the monthly number of rain days (Gerten et al., 2004). The monthly mean temperature and radiation (percent cloudless) data were converted to daily values by linear interpolation.

The historical land use data set for $0.5^{\circ}$ grid cells used in this study was constructed by Bondeau et al. (2007), combining the cropland fraction for the period 1901-1992 (Ramankutty and Foley, 1999), the distribution of different crops for 1990 (Leff et al., 2004), the pasture fraction for 1970 (Klein Goldewijk and Batjes, 1997) and the irrigated agricultural fraction for 1995 (Döll and Siebert, 1999). More details on the construction of this data set are provided in Appendix A.

We used the bimonthly maximum value composited normalised difference vegetation index (NDVI) Global Inventory Modeling and Mapping Studies (GIMMS) data set derived from the National Oceanic and Atmospheric Administration's (NOAA) series of Advanced Very High Resolution Radiometer (AVHRR) instruments with a spatial resolution of $0.07^{\circ}$ (Tucker et al., 2005). The red and nearinfrared bands of the AVHRR sensor are used to compute the NDVI, a metric that is correlated with the photosynthetic activity and LAI of green vegetation (Sellers, 1989). The NDVI also reduces variations not related to vegetation information from the effects of topography, sensor calibration and viewing geometry, while the maximum value compositing procedure minimises the effects of cloud cover and the atmosphere (Holben, 1986). Corrections for sensor differences, sensor drift and the effects of volcanic eruptions have all been accounted for in the GIMMS data set. We scaled up the NDVI observations to $0.5^{\circ}$ using mean-value aggregation, by including all overlapping cells within the larger $0.5^{\circ}$ area and by ignoring all water areas, negative values, and urban land cover (identified using the Global Land Cover Facility land cover data set, e.g. Hansen et al., 2000). We also extracted the maximum NDVI from the two NDVI estimates for each month over the whole time series in order to match the temporal frequency of LPJ-GUESS output. This has the added benefit of further reducing the effects of atmospheric disturbance in the data.

Food and Agriculture Organization of the United Nations (FAO) national crop yield data were obtained from http://faostat.fao.org/site/567/default.aspx\#ancor, accessed on 1 March 2012.

\subsection{Model experiments and evaluation}

For the period 1901-2006, the historical $\mathrm{CO}_{2}$, climate and land cover data described in Sect. 2.2 were used. Model spin-up was for $300 \mathrm{yr}$, applying the year $1901 \mathrm{CO}_{2}$ value and temperature-detrended climate data for 1901-1930 in repeated cycles. In the experiments with land use functionality turned on, the 1901 cropland and pasture fractions were used for the spin-up period. Cropland and pasture stands contained only one patch since stochastic processes of natural vegetation establishment and mortality, or disturbances by fire or other events (see Sect. 2.1), are not needed for managed ecosystems.

Two main simulations were done, either without land use functionality, simulating only potential natural vegetation (S0), or with land use change and specific representations of cropland and pasture (S1). Another simulation included land use change but with harvested grassland representing both cropland and pasture (S2). This was to enable the effects of a detailed cropland definition on net ecosystem carbon balance (NECB) to be compared with a simplified cropland representation. A number of experiments based on S1 were performed over the period 1901-2006 to investigate the sensitivity of the African continent NECB to LULCC, different management practices and changes in climate and $\mathrm{CO}_{2}$. These experiments were designed to investigate separately the relative contributions of these drivers, either by performing factorial simulations, keeping land cover, $\mathrm{CO}_{2}$, net climate or individual climate drivers at the spin-up levels (see above) while varying other drivers, and comparing these with a simulation with all drivers varying (S1), or by simply changing crop management parameters (Table 3 ).

To test the accuracy of the model to capture the seasonal vegetation greenness variation of the African continent, with and without land use functionality, modelled monthly mean fraction of absorbed photosynthetically active radiation (FPAR) was compared with observed monthly maximum NDVI for the period 1982-2006. Although FPAR and NDVI are not comparable in terms of their absolute values, they can both serve as indicators of seasonally varying phenology and leaf growth dynamics. Twelve sites located in the major African crop-intensive regions, representative of the different climate seasonalities, crop types and irrigation intensities, were selected to provide a significant crop-derived component to the total FPAR/NDVI levels (Table 4, Fig. 2).

Standardised anomalies (zscores) of FPAR and NDVI were calculated as deviations from the population mean, divided by the standard deviation. The population was all the values of monthly data either for a given site or for the entire African continent, the latter for comparisons of seasonal fluctuation amplitudes. Distances between standardised FPAR and NDVI anomalies were computed by the distance index for a site, where $N=$ number of monthly FPAR/NDVI data pairs and $\Sigma$ is the sum over all these data pairs (Eq. 1). 
Table 3. Set-up of the different LPJ-GUESS simulations.

\begin{tabular}{ll}
\hline $\mathrm{S} 0$ & Natural vegetation only, variable climate and $\mathrm{CO}_{2}$. \\
$\mathrm{S} 1$ & Natural vegetation, explicit cropland and pasture representations, variable climate, $\mathrm{CO}_{2}$ and \\
& land cover. Cover crop grass. Irrigated cropland. Standard harvest parameters. \\
$\mathrm{S} 1.1$ & As (S1), but with fixed land cover (1901 data). \\
$\mathrm{S} 1.2$ & As (S1), but with fixed climate (1901-1930 data cycled). \\
$\mathrm{S} 1.3$ & As (S1), but with fixed temperature (1901-1930 data cycled). \\
$\mathrm{S} 1.4$ & As (S1), but with fixed precipitation (1901-1930 data cycled). \\
$\mathrm{S} 1.5$ & As (S1), but with fixed radiation (1901-1930 data cycled). \\
$\mathrm{S} 1.6$ & As (S1), but with fixed CO $\mathrm{CO}_{2}$ (1901 value). \\
$\mathrm{S} 1.7$ & As (S1), but without cover crop grass. \\
$\mathrm{S} 1.8$ & As (S1), but with no crop residue removal. \\
$\mathrm{S} 1.9$ & As (S1), but with $100 \%$ crop residue removal. \\
$\mathrm{S} 2$ & Natural vegetation, cropland and pasture represented by harvested grassland. \\
& Variable climate, $\mathrm{CO}_{2}$ and land cover. \\
\hline
\end{tabular}

$\mathrm{di}=\sqrt{\frac{\sum(\mathrm{zscore}(\mathrm{FPAR})-\mathrm{zscore}(\mathrm{NDVI}))^{2}}{N}}$

\section{Results and discussion}

\subsection{Seasonal variation of vegetation greenness}

Averaged over $10-15^{\circ}$ latitude bands covering the African continent, seasonal anomalies of modelled FPAR generally matched remotely sensed NDVI well, although sometimes preceding the NDVI variation by 1-2 months (Fig. 4). In large parts of Africa, the modelled phenology is governed directly by precipitation (Fig. 2), so the accuracy of the climate data (monthly in the present study) is critical and could be a source of error. In Africa, the density of the climate sampling network is relatively sparse in many places, and this can introduce a bias in gridded climate products, especially in precipitation. A bi-seasonal pattern in NDVI evident around the Equator is accurately captured by the model. An exception to the good FPAR vs. NDVI fit is seen in the 15$25^{\circ} \mathrm{N}$ latitude band largely characterised by desert with only little vegetation. In this area, FPAR closely follows the precipitation seasonality, so the data-model mismatch probably reflects either NDVI artefacts caused, for example, by seasonal atmospheric dust clouds or poor seasonal accuracy in the climate data for this region. Adding land use functionality to LPJ-GUESS brings rather minor changes to these continental-scale seasonal FPAR patterns, reflecting the relatively small cropland fraction of Africa, which when averaged over the latitudinal bands does not exceed $9 \%$ of the area (Ramankutty and Foley, 1999). However, when focusing on a number of locations in regions with a relatively large fraction of cropland (Table 4, Fig. 2), the difference in leaf area development over the course of a year between managed land and natural vegetation is evident (Fig. 5). The most apparent deviations of LPJ-GUESS potential natural vegetation seasonal FPAR from observed NDVI are in regions where crops have replaced a natural vegetation of evergreen or mixed forest, having little or no seasonal variation. Including land use functionality improves the fit in these areas. In our examples, this is the case in temperate northern (Algeria) and southern Africa (South Africa 1), subtropical East Africa (Ethiopia) and tropical East Africa (Uganda and Tanzania).

At savannah locations (examples are for Senegal, Sudan and Burkina Faso), the growing season onset simulated as an increase in modelled natural vegetation FPAR is $2-3$ months ahead of the increase in NDVI. Accounting for land management in the model partially reduces this difference, since the crop FPAR increase is significantly delayed compared to natural vegetation and, at these locations, quite similar to the NDVI increase. In regions where natural vegetation is dominated by grasslands, including land use has little influence on the FPAR vs. NDVI fit. This is with the exception for the region in Egypt, where the modelled rain-fed natural vegetation FPAR is sparse and deviates highly from the observed NDVI levels and seasonal pattern. Two distinct growing periods are apparent in the NDVI seasonality, reflecting the irrigated double-cropping farming practice in the Nile delta. When including irrigated cropland in the model (Fig. 5), the maximum FPAR is increased to realistic levels, but at present the model can reproduce only a single growing season. Doublecropping capability is a high priority in future versions of the model, as recently introduced in the LPJ-DGVM version (Waha et al., 2013). An alternative sowing method for irrigated crops (precipitation-dependent sowing instead of the default temperature-dependent sowing) improves the timing 


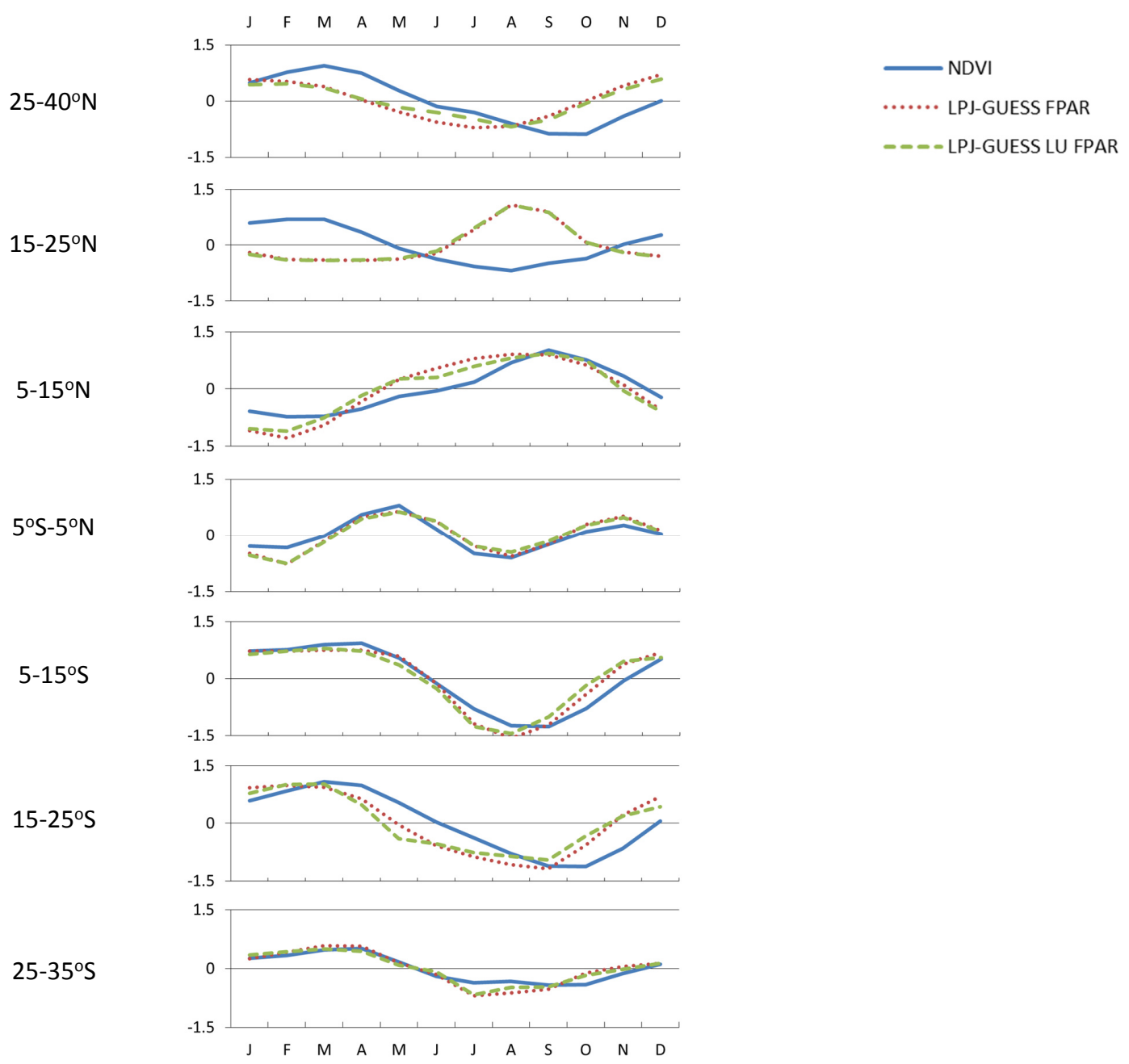

Fig. 4. Standardised anomalies of monthly observed NDVI and FPAR, modelled by LPJ-GUESS with and without land use (LU) functionality, relative to the grid cell mean and standard deviation, averaged over latitude bands for the period 1982-2006. Simulation S0, "LPJ-GUESS", represents potential natural vegetation only, while simulation S1.7, "LPJ-GUESS LU”, represents potential natural vegetation plus cropland and pasture. Cropland is simulated without cover crop grass.

of the growing season in Egypt, resembling one of the two observed growing periods (Fig. 5).

Altogether, simulations including land use improve the FPAR vs. NDVI fit of standardised intra-annual variation (seasonality) in the most crop-intensive regions across the entire continent, with the exception of the Nile valley and delta, where the seasonality of irrigated crops is better captured by modelled natural vegetation than by cropland using the default sowing method (Fig. 6).

\subsection{Inter-annual greenness variability 1982-2006}

The Sahel region has been well studied with respect to recent climatic and land cover trends. Hickler et al. (2005) showed that a positive trend in satellite-measured NDVI greenness through the 1980s and 1990s was best explained by a positive trend in precipitation over this period. Expanding this analysis to 2002, using a spatially explicit approach, accounting for additional regional effects of human land use, did not significantly improve agreement between modelled vegetation patterns and satellite observations (Seaquist et al., 2009). Anomalies of NDVI and FPAR simulated by our model, averaged over the Sahel rectangle $\left(12-20^{\circ} \mathrm{N}, 19^{\circ} \mathrm{W}-40^{\circ} \mathrm{E}\right)$ for the period 1982-2006, are shown in Fig. 7. Similarly to the previous studies cited above, an overall positive trend with correlated interannual variation in FPAR and NDVI is apparent and may be explained by variation in rainfall. After the late 1990s, the trend levels off, as observed before (Kaspersen et al., 2011). Inclusion of land use had only a minor effect on simulated FPAR, reflecting the low (c. $5 \%$ ) cropland cover in the region. 

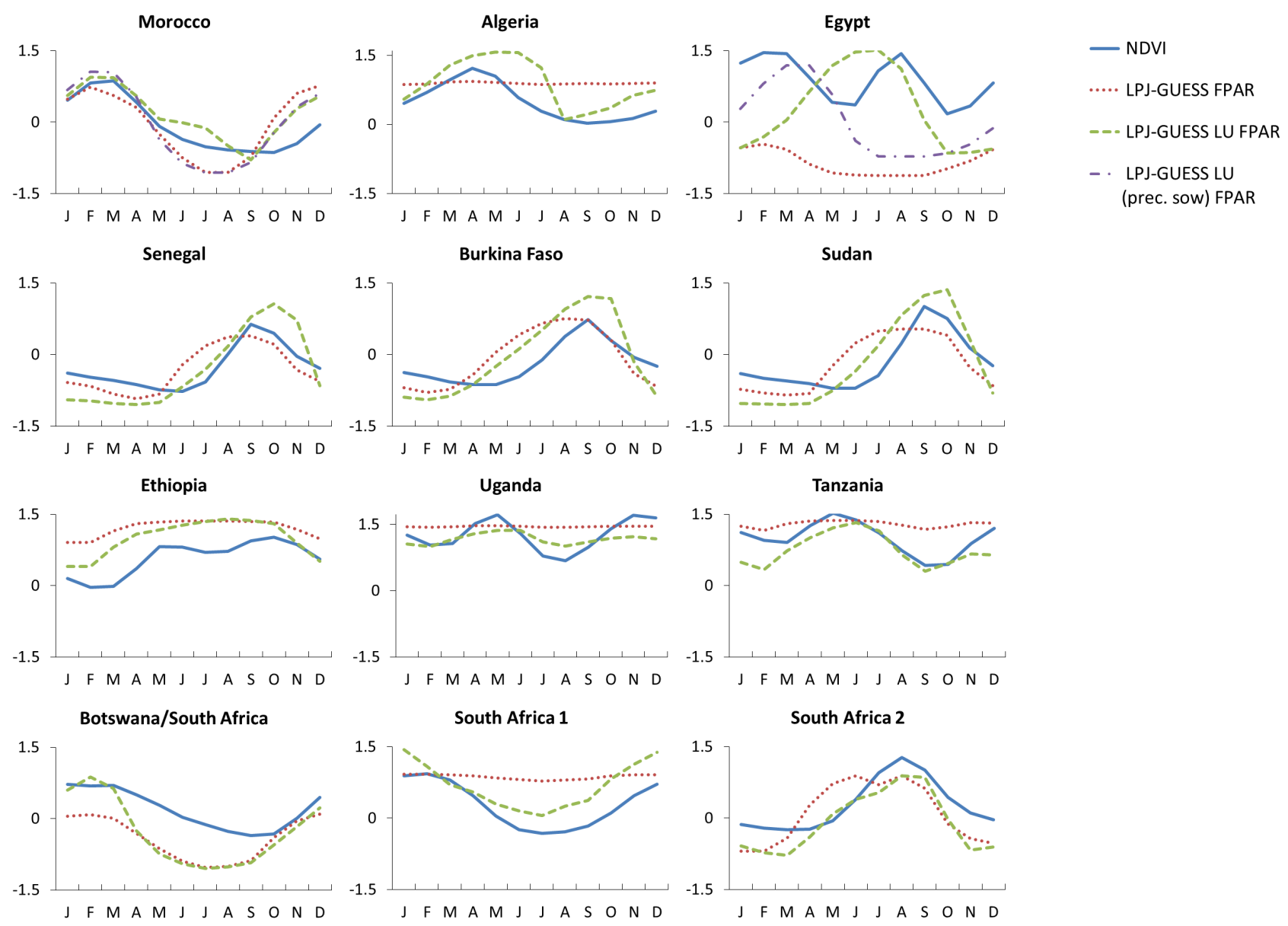

Fig. 5. Standardised anomalies (average for $4-15$ adjacent cells, see Table 4 for details) of monthly observed NDVI and FPAR, modelled by LPJ-GUESS with and without land use (LU) functionality, relative to the African total mean and standard deviation, for the period 19822006. Simulation S0, "LPJ-GUESS", represents potential natural vegetation only, while simulation S1.7, "LPJ-GUESS LU", represents potential natural vegetation plus cropland and pasture. Cropland is simulated without cover crop grass. For the Moroccan and Egyptian sites, an alternative sowing regime for irrigated crops is indicated (precipitation-dependent sowing).

\subsection{Comparing modelled crop yields with FAO statistics}

In its present configuration, LPJ-GUESS aims to reproduce crop seasonal phenology as well as potential rather than average observed yield. Modelled crop yield thus represents an upper limit for a particular location given by climate and $\mathrm{CO}_{2}$, not reduced by such factors as nutrient limitations, crop pathogens, herbivory, weeds or suboptimal farming practices. The difference between potential optimal yield and actual yield, often termed the yield gap, varies between different regions and countries. Large parts of Africa have the largest yield gaps in the world (Lobell et al., 2009; Licker et al., 2010). A comparison of modelled yields for the seven most important crops in Africa (by area), with FAO country-level crop yield statistics for the 1991-1995 period (Fig. 8), generally reflects this with higher modelled than observed yields, but for some crops, this relationship is less pronounced. There is also a variable degree of correlation between modelled and reported yield.
Modelled yields of the two major African crops, maize and tropical cereals (millet/sorghum), were almost always higher than reported yields, typically by factors ranging from 2 to 6 . In previous yield gap assessments for maize in Africa, this factor ranged from 2 to 8 (Pingali and Pandey, 2001; Lobell et al., 2009). Estimates from western Kenya of potential and actual maize yields were 3.7 and $1.7 \mathrm{tha}^{-1}$, respectively (Tittonell et al., 2008), while our results show modelled vs. reported maize yields for Kenya of 3.4 and $1.8 \mathrm{tha}^{-1}$, respectively. Combining statistical, GIS, socio-economic and methodology of agro-ecological zones for large regions of the continent, You et al. (2009) have estimated 3.5-5 tha ${ }^{-1}$ as potential yields from rain-fed, high-input maize. Modelling potential optimal millet yields in the Sahel region with the ORCHIDEE DGVM, Berg et al. (2011) obtained 25 times higher yields than FAO-reported millet yields. Temperate cereal yields were not modelled in many of the countries that report the cultivation of these crops because of the 
Table 4. Selected crop-intensive areas used in the FPAR-NDVI comparisons.

\begin{tabular}{|c|c|c|c|c|c|c|c|}
\hline Site & Position $^{1}$ & $\begin{array}{l}\text { No. } \\
\text { cells }\end{array}$ & $\begin{array}{c}\text { Cropland/ } \\
\text { pasture } \\
(\% \text { area })\end{array}$ & $\begin{array}{l}\text { Natural } \\
\text { vegetation }^{2}\end{array}$ & Crops $^{3}$ & Irrigation & Seasonality \\
\hline \multicolumn{8}{|c|}{ Northern Africa } \\
\hline Morocco & $8.5^{\circ} \mathrm{W}, 32.5^{\circ} \mathrm{N}$ & 6 & $41 / 27$ & $\mathrm{C} 3 \mathrm{~g}$ & $\mathrm{Wh}, \mathrm{Co}, \mathrm{Pu}$ & $22 \%$ & PRECTEMP \\
\hline Algeria & $6^{\circ} \mathrm{E}, 36^{\circ} \mathrm{N}$ & 8 & $59 / 27$ & $\mathrm{TeBE}$ & $\mathrm{Wh}$ & $1 \%$ & TEMPPREC \\
\hline Egypt & $30.5^{\circ} \mathrm{E}, 30.5^{\circ} \mathrm{N}$ & 6 & $58 / 26$ & $\mathrm{C} 3 \mathrm{~g}$ & Wh, Co, Ri & $94 \%$ & PRECTEMP \\
\hline \multicolumn{8}{|c|}{ Sahel } \\
\hline Senegal & $16.5^{\circ} \mathrm{W}, 13.5^{\circ} \mathrm{N}$ & 8 & $57 / 16$ & C4g, TrBR & $\mathrm{Mi}, \mathrm{Pe}$ & $4 \%$ & PREC \\
\hline Burkina Faso & $2.5^{\circ} \mathrm{W}, 12^{\circ} \mathrm{N}$ & 10 & $28 / 27$ & TrBR, C4g & $\mathrm{Mi}$ & $7 \%$ & PREC \\
\hline Sudan $1+2$ & $\begin{array}{l}33^{\circ} \mathrm{E}, 11.5^{\circ} \mathrm{N} / \\
35^{\circ} \mathrm{E}, 13^{\circ} \mathrm{N}\end{array}$ & 10 & $66 / 17$ & TrBR, C4g & $\mathrm{Mi}, \mathrm{Pe}, \mathrm{Wh}^{4}$ & $7 \%$ & PREC \\
\hline \multicolumn{8}{|c|}{ East Africa } \\
\hline Ethiopia & $37^{\circ} \mathrm{E}, 5.5^{\circ} \mathrm{N}$ & 15 & $35 / 23$ & TrBE, C3g & $\mathrm{Wh}^{4}, \mathrm{Co}, \mathrm{Mi}, \mathrm{Pu}$ & $1 \%$ & PREC \\
\hline Uganda & $31^{\circ} \mathrm{E}, 0.5^{\circ} \mathrm{S}$ & 4 & $38 / 42$ & TrBE, TrBR & $\mathrm{Pu}, \mathrm{Mi}, \mathrm{Co}, \mathrm{Ma}$ & $2 \%$ & PREC \\
\hline Tanzania & $38^{\circ} \mathrm{E}, 6^{\circ} \mathrm{S}$ & 4 & $51 / 28$ & TrBE, TrBR & $\mathrm{Co}, \mathrm{Mi}, \mathrm{Ma}, \mathrm{Pu}$ & $8 \%$ & PREC \\
\hline \multicolumn{8}{|c|}{ Southern Africa } \\
\hline $\begin{array}{l}\text { Botswana/South } \\
\text { Africa }\end{array}$ & $26.5^{\circ} \mathrm{E}, 24^{\circ} \mathrm{S}$ & 8 & $40 / 30$ & $\mathrm{C} 3 \mathrm{~g}$ & $\mathrm{Mi}, \mathrm{Co}, \mathrm{Wh}$ & $2 \%$ & PRECTEMP \\
\hline South Africa 1 & $28^{\circ} \mathrm{E}, 28.5^{\circ} \mathrm{S}$ & 6 & $40 / 29$ & TrBE, C4g, MNE & Co, Wh, Sf & $2 \%$ & TEMPPREC \\
\hline South Africa 2 & $18^{\circ} \mathrm{E}, 33.5^{\circ} \mathrm{S}$ & 4 & $60 / 24$ & $\mathrm{C} 3 \mathrm{~g}$ & Co, Wh, Sf & $3 \%$ & PRECTEMP \\
\hline
\end{tabular}

set upper temperature limit for this PFT (see Methods), but this was found to be of minor importance as the reported area covered by temperate cereals was small in most countries. In the remaining nine African countries, modelled temperate cereal yields were equal to or higher than reported yields. For pulses, the relationship between modelled vs. reported yields could be separated into different regions, with one group consisting of Sahel countries with a low modelled yield of up to $1 \mathrm{tha}^{-1}$, a second group containing the majority of countries (mostly tropical) with a modelled yield of $2-4 \mathrm{tha}^{-1}$, and a third small group of countries (Morocco, Tunisia, Egypt and Lesotho), with a modelled yield of $7-9 \mathrm{tha}^{-1}$ (Fig. 8). With the exception of Egypt, probably because of irrigation, the reported yield was only up to $1 \mathrm{tha}^{-1}$, resulting in large differences in estimated yield gaps for the three groups.

Reported yields exceeded modelled yields for some crops (e.g. peanut) in a few regions (e.g. the Sahel) possibly reflecting poor yield statistics or climate data for that region (see the discussion on FAO statistics in the Sahel in Berg et al., 2011) but probably also poor quality of the crop distribution in the land use data set used. Cassava shows a very poor correlation between modelled and reported yield. Cassava is mainly grown in regions with little climate variability, suggesting that non-climatic factors, not represented by our model, may explain some of the reported variation in reported yields.

Interannual variability of simulated and reported yields is a further indicator of model performance. Simulated variation in maize yields for the period 1971-2005 shows acceptable general agreement with observed yields, especially for certain countries (e.g. South Africa and Zimbabwe), reflecting a strong climate component to crop productivity and probably also better-than-average crop statistics (Fig. 9). The results shown for maize are representative of most crops in these countries.

In addition to the known uncertainties in climate input and reported yield statistics (Hall, 1984), irrigation fractions are currently only rough estimates for each crop (cf. Bondeau et al., 2007). Unsurprisingly, irrigation can increase simulated yields substantially, but modelled rain-fed crop yields also exceed reported yields in most countries (Fig. 9a). The irrigated area in Africa is well below $5 \%$ of the crop area (You et al., 2009), but large scale irrigation is probably less costeffective than general improvements in agricultural practices to decrease the yield gap in African regions, or as an adaptive measure to mitigate climate change impacts (Liu et al., 2008; Ziervogel et al., 2008). 
$\triangle \mathrm{NDVI} /$ FPAR distance index (di)

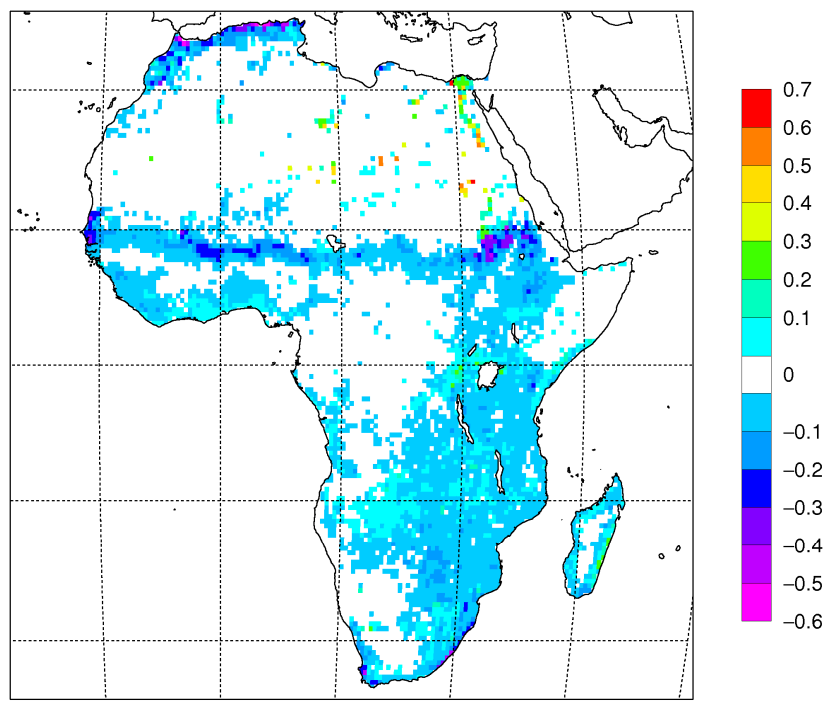

Fig. 6. Difference in distance index (di) for monthly observed NDVI and modelled FPAR between a simulation with specific representations of cropland and pasture (S1.7) and a simulation with natural vegetation only (S0) for the period 1982-2006. Cropland is simulated without cover crop grass and with the default sowing method (temperature-dependent) for irrigated crops. Negative values are improvements to the FPAR vs. NDVI fit of standardised seasonal variation. Grid cells where the year 1992 cropland fraction is below $2 \%$ are masked out.

\subsection{Modelling carbon fluxes of natural vegetation, pasture and croplands}

African continent cumulative NECB simulated for 19012006, with and without representations of cropland, pasture and land use change and under alternative management options, is shown in Fig. 10a. Positive values represent a net flux to the atmosphere, negative values a flux into ecosystems. When modelling potential natural vegetation only (S0), Africa as a whole was estimated to accrue $21.8 \mathrm{PgC}$ from the atmosphere during this period. When land use was accounted for, with explicit representations of pasture and cropland, as well as land use change (S1), this sink was reduced to $14.4 \mathrm{PgC}$. Land use change alone accounted for a $3.1 \mathrm{PgC}$ flux to the atmosphere (Fig. 11a), while the rest of the reduction $(4.3 \mathrm{PgC})$ was due to the differential carbon balance of the simulated potential natural vegetation and managed land (at the 1901 cover). Pasture accounts for the majority of the difference, often replacing natural woodland (S0), which is an overall sink for carbon under present-day forcing, with $\mathrm{C}_{4}$-dominated grassland (S1), which is an overall source (Table 5). An alternative model set-up including land use change with harvested grass representing both pasture and cropland (S2) produced a similar NECB (Fig. 10). Different cropland management options in S1 had a large effect
Table 5. Cumulative NECB (PgC) 1901-2006 for the African continent in the different land covers in the various simulations ${ }^{1}$.

\begin{tabular}{lcllll}
\hline Simulation & $\begin{array}{c}\text { Natural } \\
\text { vegetation }\end{array}$ & Pasture & Cropland & $\begin{array}{c}\text { Land use } \\
\text { change }^{2}\end{array}$ & Total \\
\hline S0 & PNV & PNV & PNV & & \\
& -17.5 & -3.9 & -0.47 & - & -21.8 \\
S1 & PNV & Grass PFTs & Crop PFTs & & \\
& -17.5 & +0.42 & -0.22 & +2.8 & -14.4 \\
S2 & PNV & Grass PFTs & Grass PFTs & & \\
& -17.5 & +0.42 & -0.37 & +2.8 & -14.6 \\
\hline
\end{tabular}

${ }^{1} \mathrm{NECB}$, net ecosystem carbon balance $(\mathrm{PgC})$; the $\mathrm{S} 0, \mathrm{~S} 1$ and $\mathrm{S} 2$ simulations differ in the way pasture and cropland are represented: by potential natural vegetation (PNV), grass PFTs or crop PFTs; ${ }^{2}$ land use change here denotes only carbon losses from harvested PNV above-ground carbon.

on the carbon balance, as has previously been suggested, for example, by Lal (2002). When $100 \%$ crop residue removal was assumed, the carbon sink was reduced by $1.4 \mathrm{PgC} \mathrm{com-}$ pared to no removal. Grass cover crop growth added $1.2 \mathrm{PgC}$ to the sink compared to no cover crop. In our model, alternative cropping practices thus had the potential to influence the biosphere-atmosphere carbon balance significantly, underlining the need for valid characterisation of land management practices in models as well as good estimates of land cover change per se.

Model-based studies of transient changes in the global terrestrial ecosystem carbon balance over the 20th century indicate a switch from a neutral or source to a sink state around 1960 as a result of saturation of land use expansion, accompanied by increased greenhouse gas emissions, raising the production enhancement of vegetation due to atmospheric $\mathrm{CO}_{2}$ (McGuire et al., 2001; Le Quéré et al., 2009; Ahlström et al., 2012b). Similar global transient responses were obtained by Bondeau et al. (2007). In our simulation, the African continent turned from being neutral to being a carbon sink already around 1950 (Fig. 10). The earlier transition to carbon uptake for the African continent, compared to global patterns, may be attributed to the continent's lower deforestation rates in the 20th century, compared to other regions (e.g. South America) (Ciais et al., 2009). Short episodes of carbon release in the 1940s and 1980s correlated with periods of relatively warm and dry climate, conditions under which reduced plant production tends to coincide with increased heterotrophic respiration and wildfire biomass burning in the model (Fig. 11b).

The modelled African continent NECB averages for the periods 1980-1989, 1990-1999 and 2000-2005 were 0.16, -0.27 and $-0.60 \mathrm{PgC} \mathrm{yr}^{-1}$, respectively, when land use was accounted for. The change from a carbon source in the 1980s to a sink in the 1990s for African vegetation was also seen by Ciais et al. (2009), modelling the impact of land use change using the vegetation model ORCHIDEE ( 0.14 and $-0.15 \mathrm{PgC} \mathrm{yr}^{-1}$, respectively). The land use change component of the NECB for the $1980 \mathrm{~s}$ was $0.07 \mathrm{PgC} \mathrm{yr}^{-1}$. Previous studies using the same historical cropland fraction data as in 


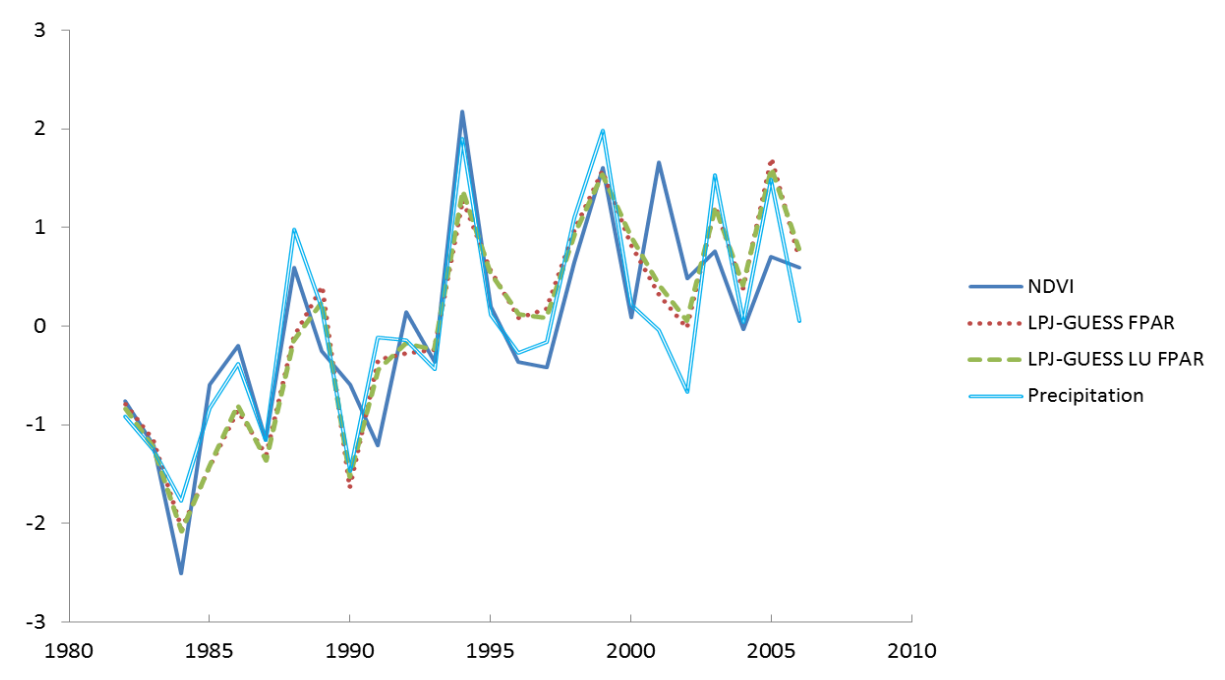

Fig. 7. Standardised mean anomalies for the Sahel region of yearly maximum observed NDVI and FPAR, modelled by LPJ-GUESS with and without land use functionality, and precipitation for the period 1982-2006.
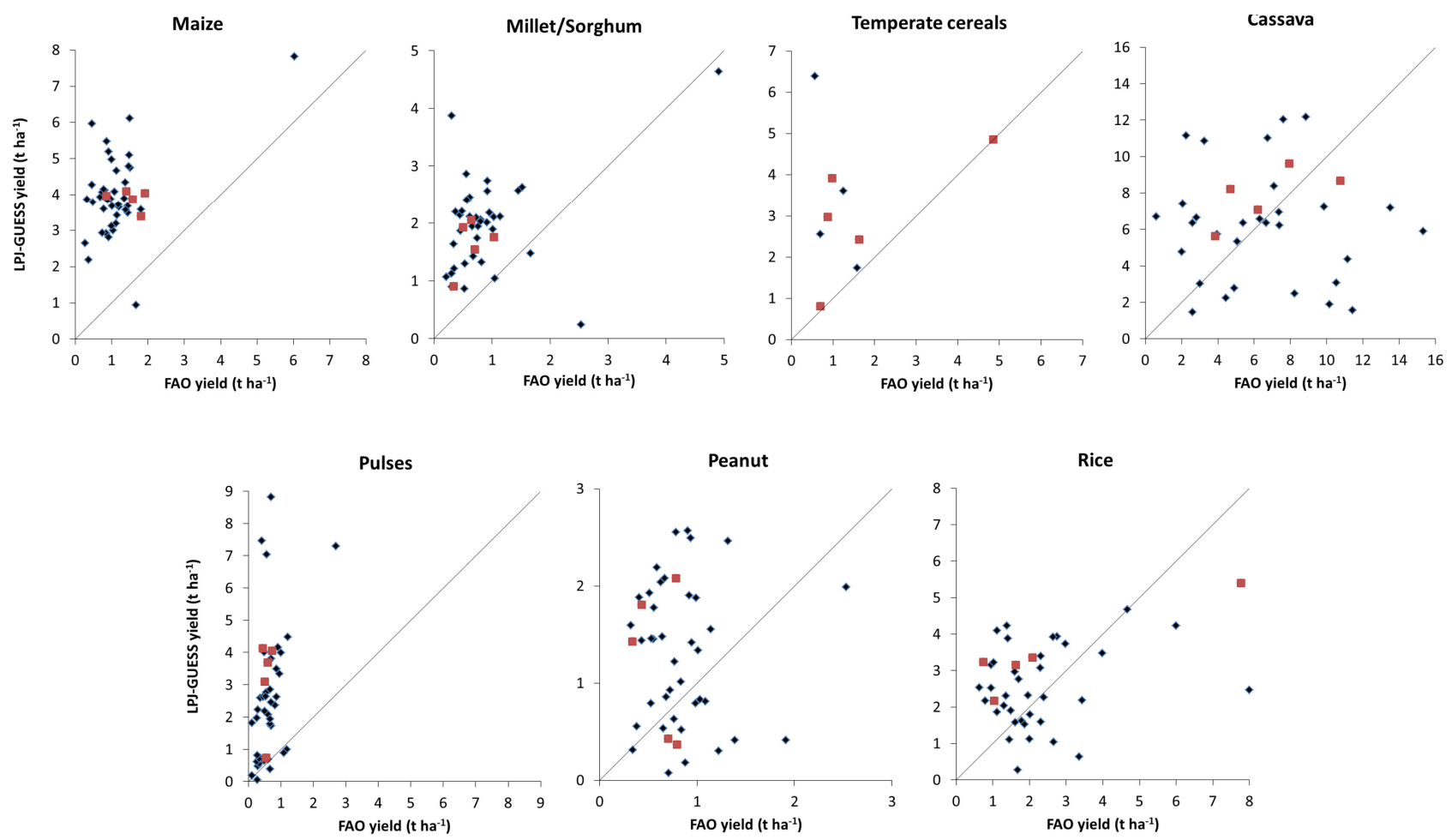

Fig. 8. Scatter plots of LPJ-GUESS modelled yield versus FAO reported yield of the seven most widespread crops in Africa (1991-1995 country means). The five countries with the largest area of each crop are indicated in red. Countries where temperate cereals could not grow because of the upper temperature limit are excluded from the scatter plot.

this study (Ramankutty and Foley, 1999), with two different vegetation/carbon cycle models, produced similar land-usechange-derived carbon fluxes for the $1980 \mathrm{~s}, 0.08 \mathrm{PgC} \mathrm{yr}^{-1}$ for tropical Africa (Jain and Yang, 2005) and 0.08 $\mathrm{PgC} \mathrm{yr}^{-1}$ for the continent as a whole (Ciais et al., 2009). A bookkeeping model of vegetation-atmosphere carbon fluxes with land use change input based on deforestation rates produced either similar $\left(0.09 \mathrm{PgC} \mathrm{yr}^{-1}\right.$ for 1984-1990, DeFries et al., 2002) or higher $\left(0.3 \mathrm{PgC} \mathrm{yr}^{-1}\right.$ for $1980-1989$, Houghton, 2003) results for tropical Africa, depending on the input data. The land use input data, rather than the model used, have been implicated as the main factor explaining the 

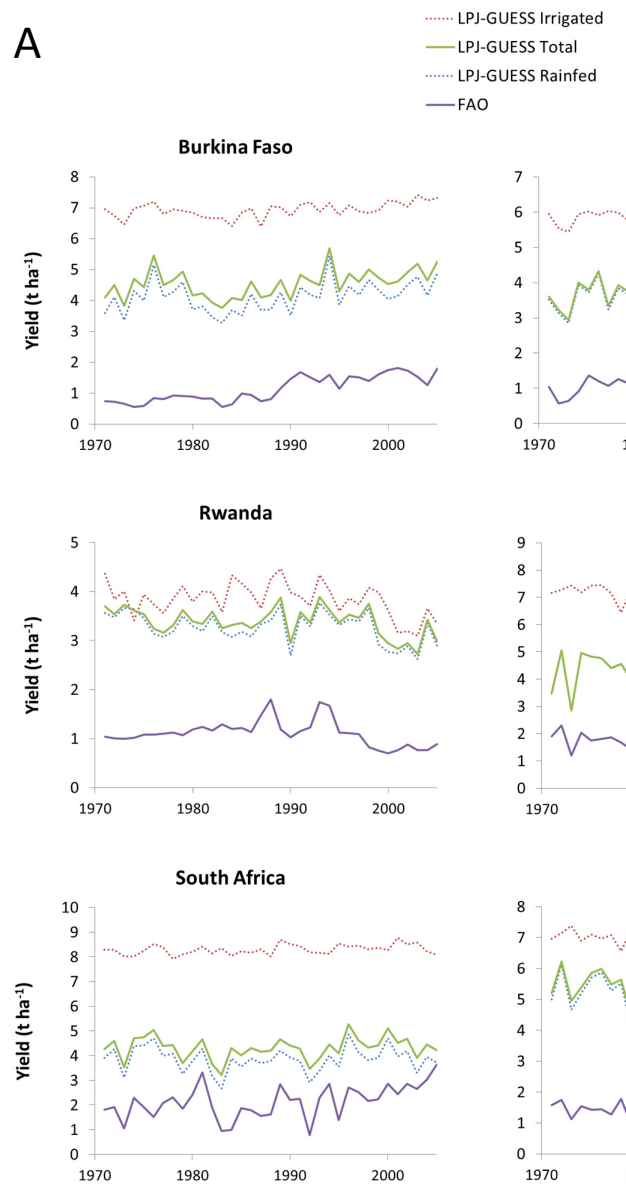
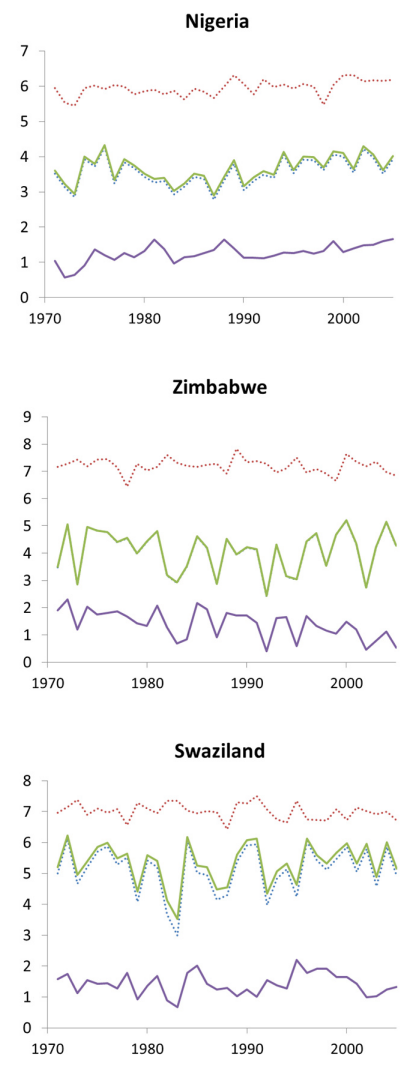

B
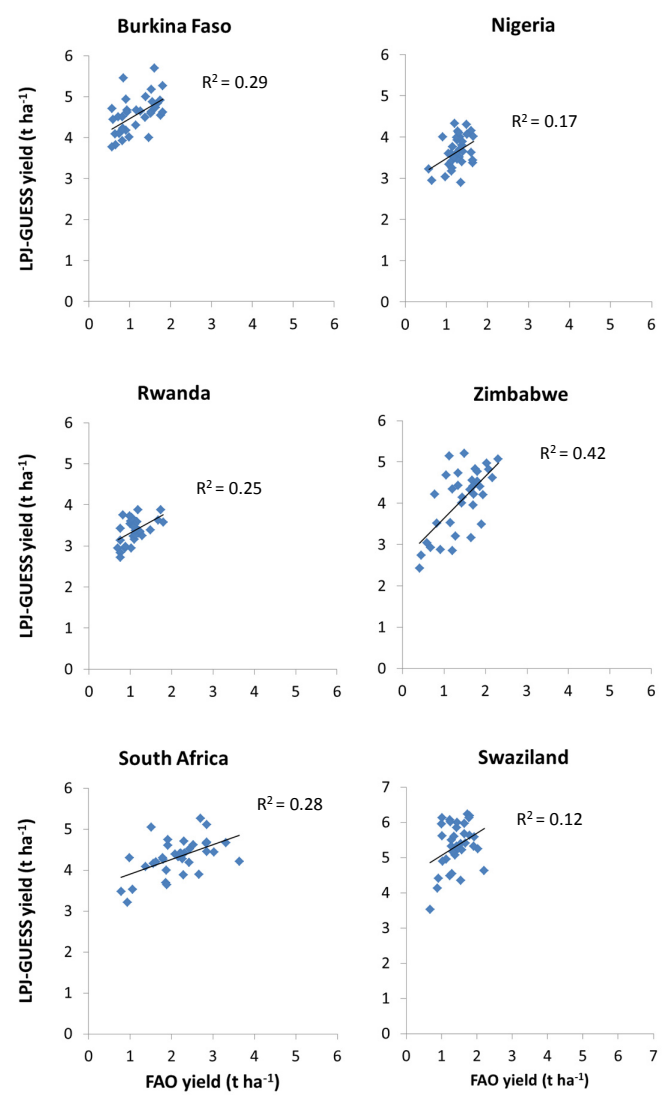

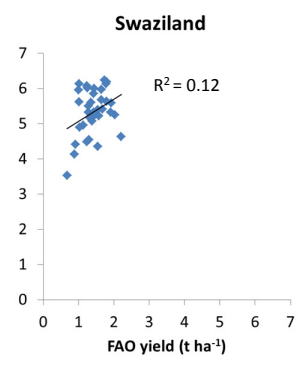

Fig. 9. (A) Time series of LPJ-GUESS modelled irrigated, rain-fed and average yields and reported FAO yields for maize 1971-2005 for selected African countries. (B) Scatter plot of LPJ-GUESS modelled versus FAO reported maize yields 1971-2005 with linear regression lines. Countries were selected that lacked obvious artefacts in the yield interannual data (e.g. constant data and abrupt shifts) and that showed clear correlation with modelled yields.

differences in carbon balance estimates obtained by different studies (McGuire et al., 2001; Jain and Yang, 2005). Bondeau et al. (2007) showed that using the IMAGE land use data (IMAGE team, 2001) instead of the Ramankutty and Foley (1999) land cover data to drive LPJ-mL resulted in global carbon fluxes much more in agreement with high estimates based on bookkeeping (Houghton, 2003).

With respect to geographic location, African regions with a large fraction of managed land generally had similar 19611990 average annual NECB compared to potential natural vegetation, but some cropland-intensive areas in East Africa had NECB values up to $0.28 \mathrm{~kg} \mathrm{C} \mathrm{m}^{-2} \mathrm{yr}^{-1}$ higher with land use taken into account (Fig. 12a). Part of this is due to a land-use-change-derived $\mathrm{CO}_{2}$ release to the atmosphere (up to $0.22 \mathrm{~kg} \mathrm{C} \mathrm{m}^{-2} \mathrm{yr}^{-1}$ ) (Fig. 12b). $\mathrm{CO}_{2}$ captured by abandoned cropland in Africa during this period is minimal, since this area is very small (Fig. A3).

The results from factorial driver simulations, shown in Fig. 11, suggest that $\mathrm{CO}_{2}$ fertilisation had a greater influence on African NECB (-22.9 PgC for the period 1901-2006) than climate change $(+6.3 \mathrm{PgC})$, land use change $(+3.1 \mathrm{PgC})$ or alternative cropland management (up to $2.2 \mathrm{PgC}$ ). In managed land, the $\mathrm{CO}_{2}$ fertilisation effect is reduced relative to potential natural vegetation, due to a higher proportion of $\mathrm{C}_{4}$ grasses in pasture and $\mathrm{C}_{4}$ crops in cropland, which lack the strong physiological response of $\mathrm{C}_{3}$ plants to elevated $\mathrm{CO}_{2}$ (Fig. B1). However, the magnitude of the $\mathrm{CO}_{2}$ fertilisation effect is unclear from observations (e.g. in cropland free-air $\mathrm{CO}_{2}$ enrichment - FACE - experiments; Long et al., 2006; Tubiello et al., 2007), leading to some uncertainties in the capabilities of DGVMs to account for it correctly. For the 1980s, the relative NECB contributions of both climate and $\mathrm{CO}_{2}\left(+0.5\right.$ and $-0.3 \mathrm{PgC} \mathrm{yr}^{-1}$, respectively) were much higher than that of land use change $\left(+0.07 \mathrm{PgC} \mathrm{yr}^{-1}\right)$. Separating the climate components, temperature and precipitation both contributed to a net flux to the atmosphere when synchronised, as in the warm and dry 1980-1996 period. After 1996, precipitation shows a positive trend, resulting in 
A

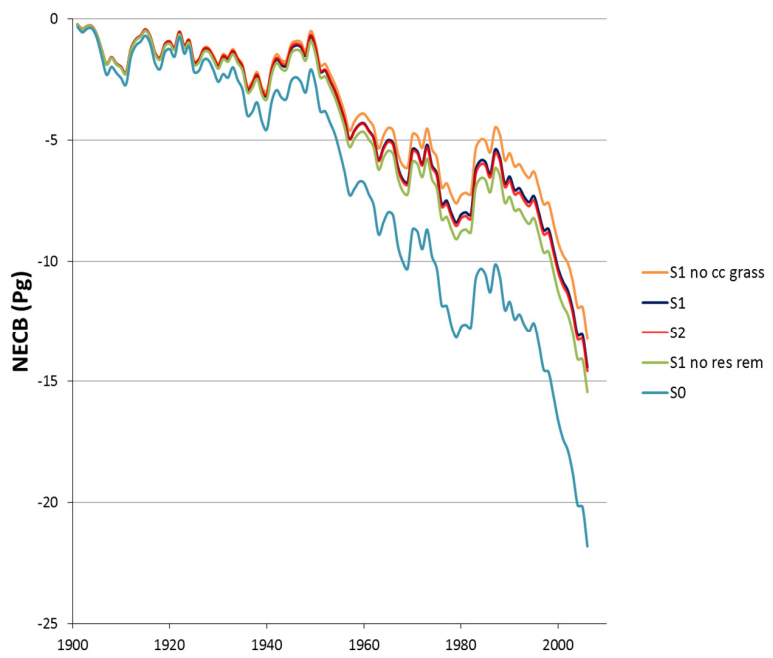

B

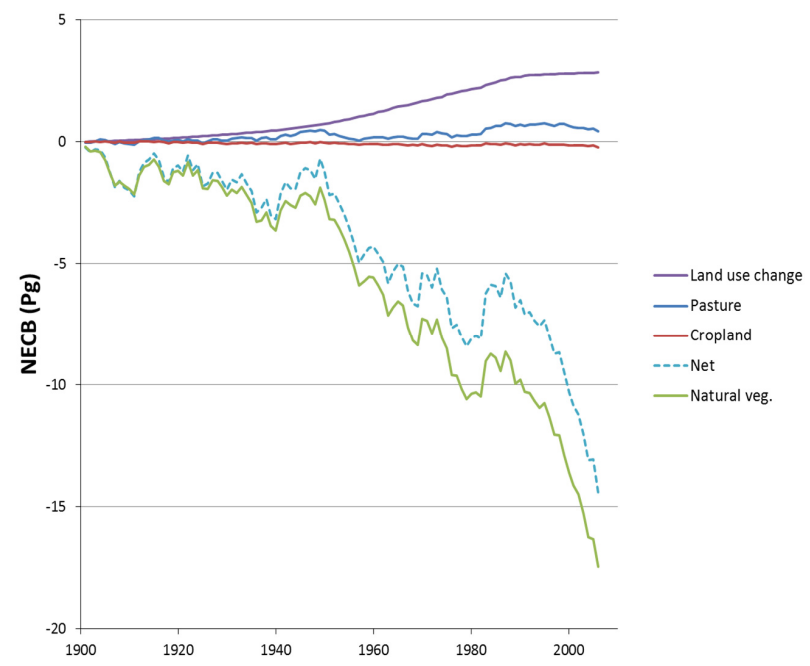

Fig. 10. (A) Modelled cumulative net ecosystem carbon balance (NECB) for the African continent in simulations with different land use and crop management settings: S0, potential natural vegetation (PNV) only ("S0"); S1, PNV plus explicit representations of cropland and pasture, including land use change, with standard crop management settings ( $90 \%$ harvest efficiency, $75 \%$ crop residue removal, cover crop grass growth and full irrigation of irrigated cropland ("S1")); S1.8, without crop residue removal ("S1 no res rem"); S1.7, without cover crop grass ("S1 no cc grass"); and S2, PNV plus grassland representing both cropland and pasture, including land use change ("S2"). (B) S1 simulation ("Net") NECB separated into natural vegetation, pasture and cropland land covers and the land use change component, derived from the harvested carbon of natural vegetation converted into cropland. Positive values represent a flux to the atmosphere.

A

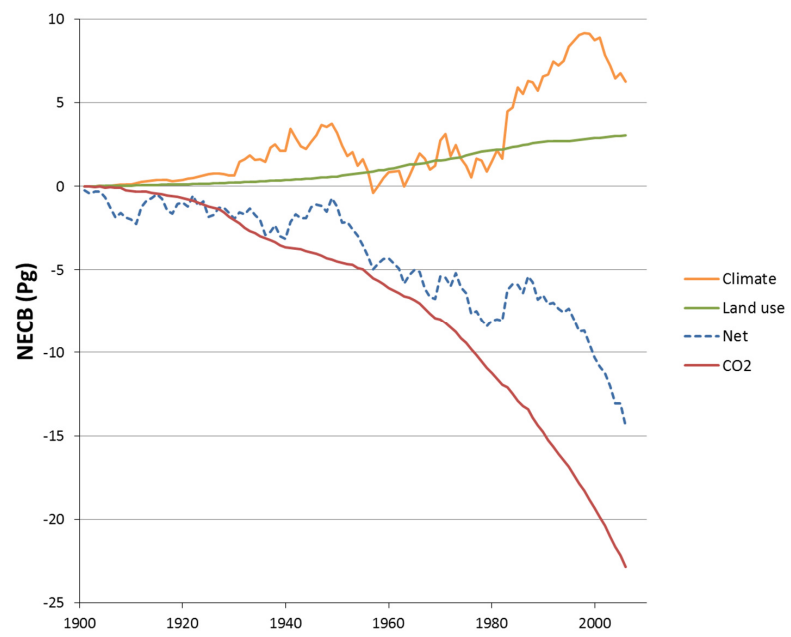

B

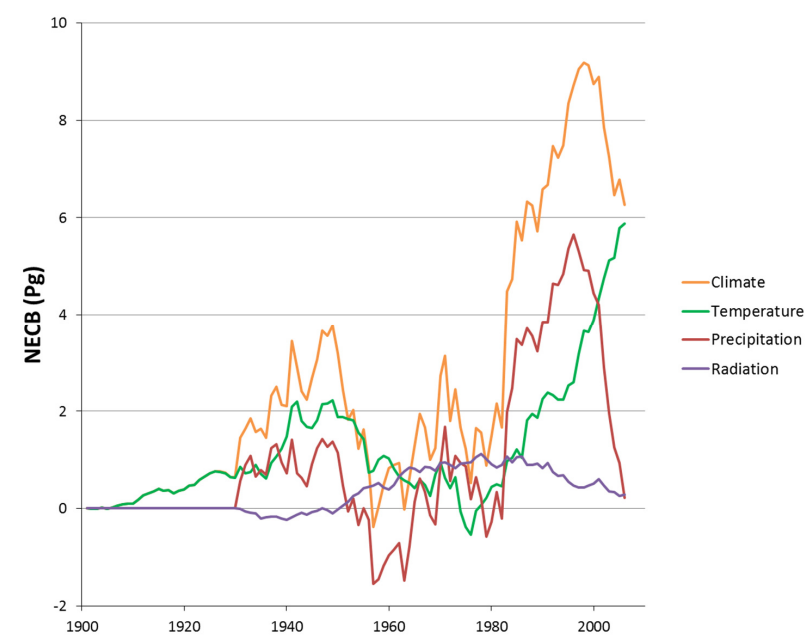

Fig. 11. (A) Separate contributions of $\mathrm{CO}_{2}$, climate and land use change to the modelled 1901-2006 cumulative net ecosystem carbon balance (NECB) for the African continent, derived by comparing a simulation (S1, "Net") forced by historical $\mathrm{CO}_{2}$, climate and land use with separate simulations where one of these components was kept at the spin-up levels throughout the simulation period (see Table 3). For example, the climate component ("Climate") was derived by subtracting the cumulative NECB of a simulation that considered only $\mathrm{CO}_{2}$ and land use change from the "Net" simulation that considered $\mathrm{CO}_{2}$, land use and climate change. (B) Separate contributions of changing temperature, precipitation and radiation to the modelled 1901-2006 cumulative African NECB, derived by comparing the "Net" simulation above with separate simulations where one climate component was kept at the spin-up levels throughout the simulation period as in (A). "Climate" is the net climate component as in (A). Positive values represent a flux to the atmosphere. 
A

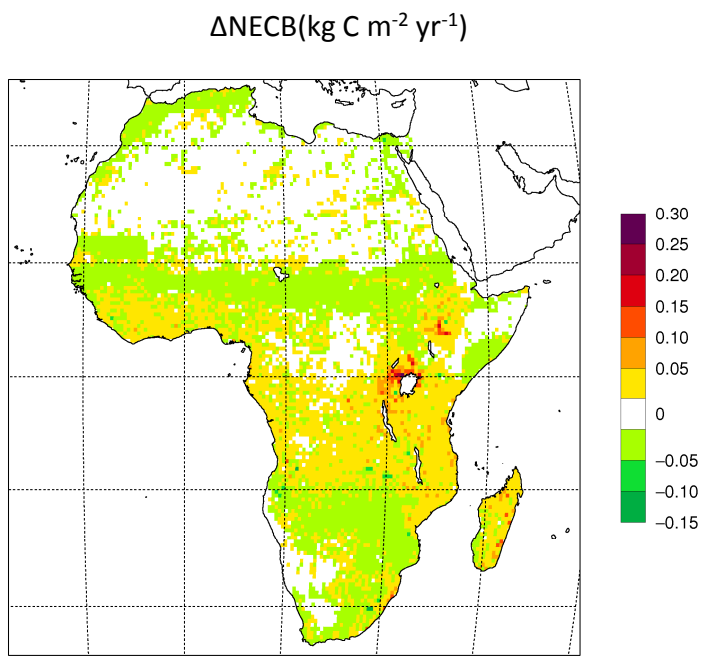

B

Land use change $\mathrm{C}$ flux $\left(\mathrm{kg} \mathrm{C} \mathrm{m}^{-2} \mathrm{yr}^{-1}\right)$

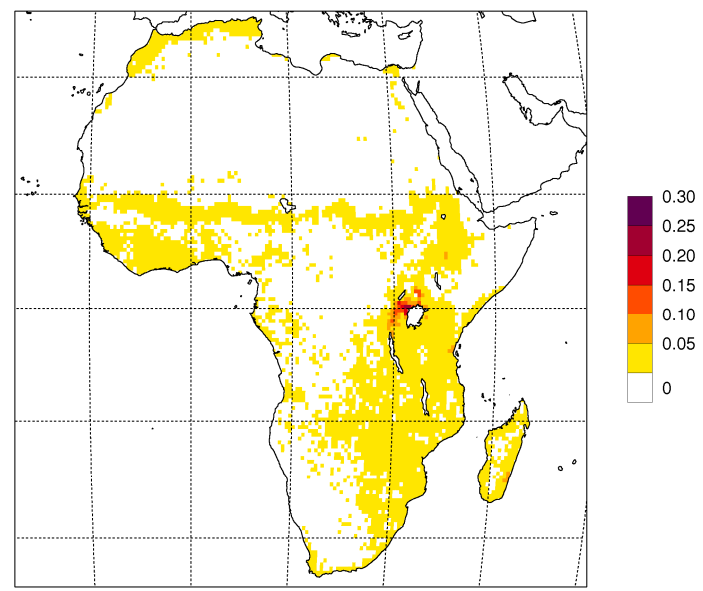

Fig. 12. (A) Difference in modelled net ecosystem carbon balance (NECB) between LP-GUESS with (simulation S1) and without (simulation S0) land use functionality (cropland and pasture representations and land use change). Positive values indicate grid cells where land use functionality reduces the carbon sink compared to potential natural vegetation only. (B) Carbon fluxes associated with land use change (not including carbon added to litter). The values are the means for the period 1961-1990. Positive values represent a flux to the atmosphere.

a net carbon uptake by the vegetation, overriding the negative, evapotranspiration-mediated effect of rising temperatures on ecosystem productivity. Over the period 1901-2006, the modelled net cumulative NECB in our study is strongly affected by the rising trend in annual mean temperatures, but the net effect of precipitation and radiation for this period is close to zero. NECB in tropical regions is positively correlated with temperature and negatively correlated with precipitation when modelled by 10 different global dynamic vegetation models (Piao et al., 2013). This is also seen in our study for Africa (as in the study of Ciais et al., 2011), but after 1991, the correlation with temperature is reduced by the strong effects of rising precipitation (Fig. B2). Modelled gross primary production (GPP) and NECB of the inner tropics of Africa appear to be limited by radiation in some vegetation models (e.g. LPJ-DGVM) but not in LPJ-GUESS (Weber et al., 2009). This is also reflected by our results, where modelled NECB for the African continent is uncorrelated with radiation (Fig. B2).

Our simulations are of the potential productivity of managed land given plant resource availability mediated by the prevailing climate and available information on irrigation practices. We do not account for suboptimal fertilisation and irrigation and other management aspects that may contribute to reducing actual yields below the biophysical potential (the yield gap). The simulated NECB estimates are thus likely to overestimate the actual carbon storage. A possible overestimation of crop biomass will also be reflected in an overestimation of the impact of crop harvest and residue removal on NECB. However, secondary factors such as losses during transport and storage, which also contribute to reducing the reported yield, will not influence the NECB.

\section{Conclusions}

We demonstrate the implications of introducing dynamic land management and land cover to a process-based dynamic ecosystem model in simulations over Africa. The correspondence between modelled and observed seasonal variation of vegetation cover in regions with a high cropland area fraction was improved by accounting for land use. Modelled crop yields, representing potential optimal yields, were in most cases in line with reported yields and corresponding yield gaps, when these were available. Land-atmosphere carbon balance estimates over Africa were changed significantly by introducing land use to the model, suggesting that the anthropogenic influence on vegetation cover and dynamics is important to consider in studies of the regional carbon balance, even in regions where anthropogenic impacts on landscapes are arguably only moderate by world standards.

Our results demonstrate the applicability of land-useenabled DGVMs to assessing the individual and combined impacts of climate, management and land use policy on regional carbon balances and agricultural production. As a process-based model with a uniquely detailed implementation of vegetation dynamics, LPJ-GUESS should prove useful particularly for applications under scenarios of the future world, in which environmental conditions without modern analogues may break empirical relationships between drivers and outcomes of ecosystem functioning. Updates presented 
here of the representation of crops and land management initially developed by Bondeau et al. (2007) also allow for more flexibility concerning ecosystem responses to future climate and $\mathrm{CO}_{2}$.

Improvements to the model currently under development include soil and vegetation nitrogen cycling and $\mathrm{N}$ limits on plant production, which should benefit the modelling of both crop production and vegetation succession of abandoned cropland, especially on tropical soils with low nutrient status. For applications to Africa, refined land cover and climate (especially precipitation) input data may be expected to improve the accuracy and utility of the model.

\section{Appendix A}

\section{Description of the land cover database used in this study}

The land use data set was constructed with the objective of providing the annual cover fraction of each agricultural stand that can be simulated by LPJmL (Bondeau et al., 2007). The historical cropland fraction is provided at a $0.5^{\circ}$ spatial resolution by Ramankutty and Foley (1999) for the period 19011992. A simplified land cover change model was used by Ramankutty and Foley to extend the 1992 cropland cover, derived from satellite data calibrated by cropland inventory data, back in time. They used historical national and subnational cropland inventory data and assumed the cropland spatial distribution within these political units to be constant (Ramankutty and Foley, 1999). For the period 1993-2006, we assumed the cropland fraction to remain constant at the 1992 level for simplicity. We estimated the grid cell pasture fraction after comparing the cropland fraction of Ramankutty and Foley (1999), which does not include grassland, and the crop classification of the HYDE data set for 1970 (Klein Goldewijk and Batjes, 1997), which includes the class "grass and fodder". The changes in the cropland fraction (as given by Ramankutty and Foley, 1999) translate within the model into expansion of croplands in place of natural vegetation, or into regrowth of natural vegetation after abandonment of croplands. The pasture fraction remains constant.

To determine the proportion of the different crop PFTs within the cropland fraction, we used the distribution of the 18 major crops for 1990 as provided by Leff et al. (2004). We assigned each of the 18 crop PFTs to one of our crop PFTs, assuming the relative proportion of the different crops within each grid cell to be constant during the simulation period. Döll and Siebert (1999) provide the areas equipped for irrigation in 1995 at a $0.5^{\circ}$ spatial resolution. We assume that these areas are effectively irrigated in the absence of better information. Using the irrigated fraction and the crop distribution within each grid cell, as well as a priority list for the irrigated crops (see Bondeau et al., 2007, Table 1), we determined the cover fraction of the rain-fed and irrigated crop PFTs for 1995. Following the linear trend for global

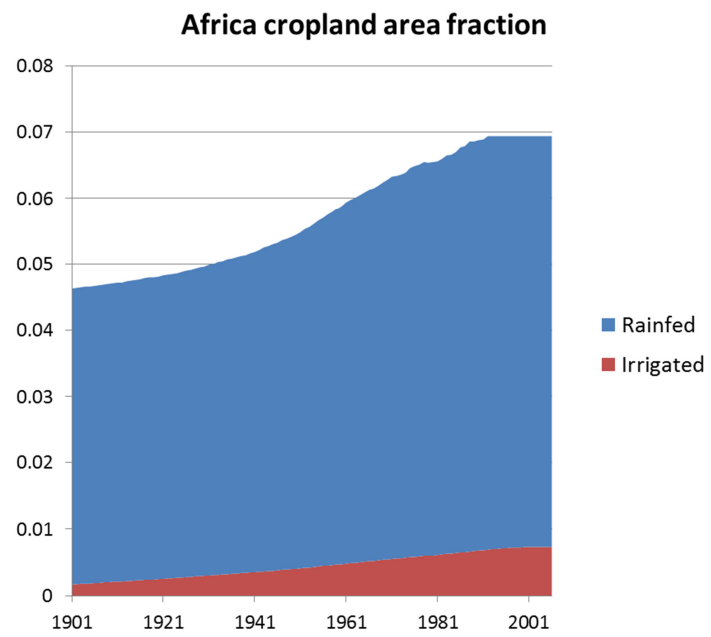

Fig. A1. Irrigated and rain-fed cropland fraction of Africa's total area during the period 1901-2006 derived from the cropland fraction for the period 1901-1992 (Ramankutty and Foley, 1999), the irrigated agricultural fraction for 1995 (Döll and Siebert, 1999) and the linear trend for global irrigation (Evans, 1997).

irrigation provided by Evans (1997), we interpolated the irrigated crop fractions back in time by assuming that only rice was irrigated in 1901.

The Figs. A1 to A5 illustrate various land use features of Africa that characterise either the original data sets or some specific step in the construction of the land use data set. 
A

1901

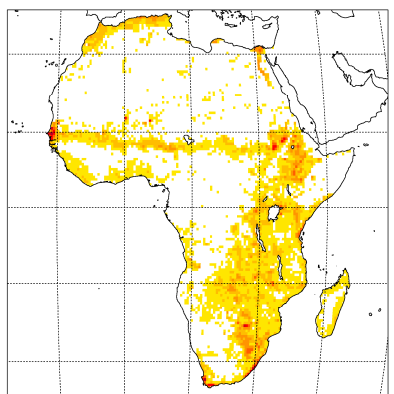

1992

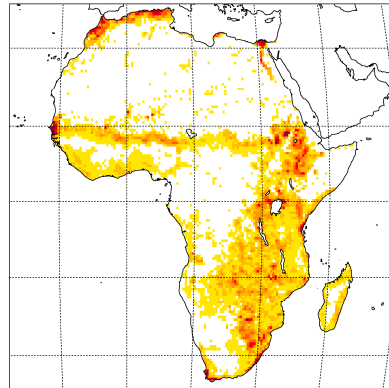

Cropland fraction

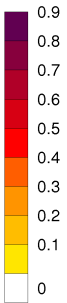

B

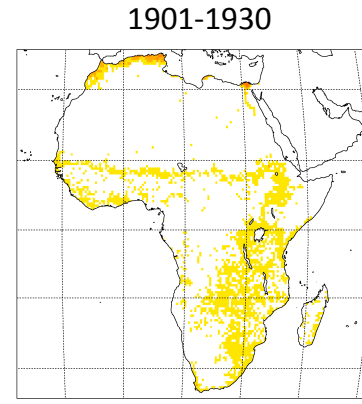

$1931-1960$

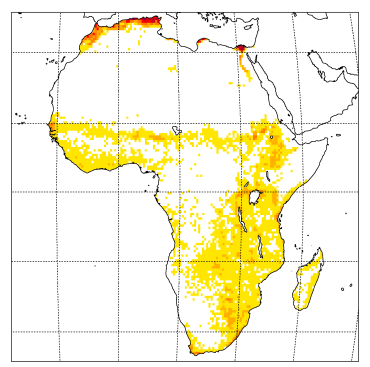

1961-1990

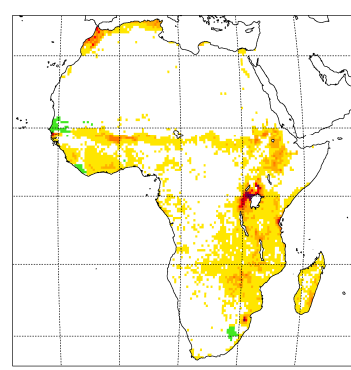

Cropland fraction change

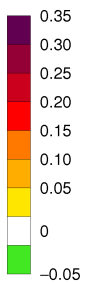

Fig. A2. (A.) Cropland fractions for the years 1901 and 1992. (B) Cropland fraction change for the time periods 1901-1930, 1931-1960 and 1961-1990. Green areas represent cropland abandonment. Values are derived from Ramankutty and Foley (1999).

A

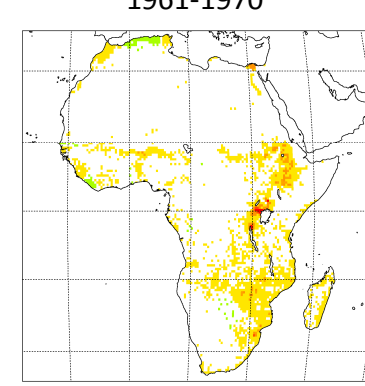

B

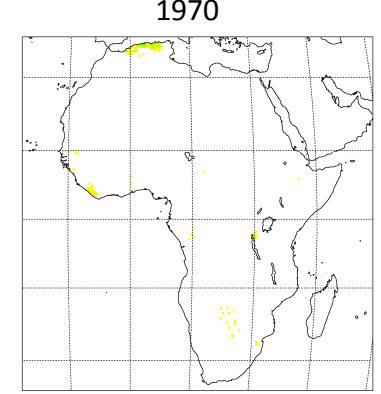

1971-1980

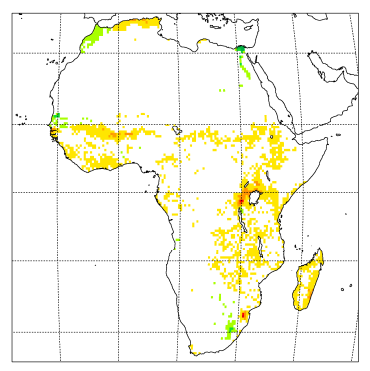

1980

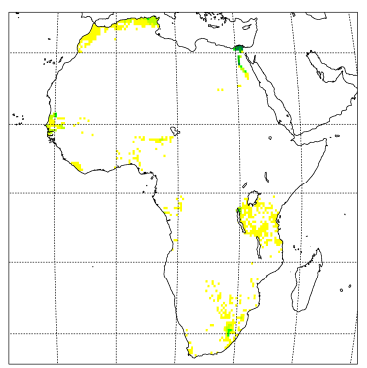

1981-1990

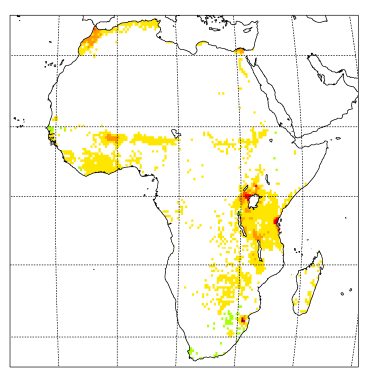

Cropland fraction

change

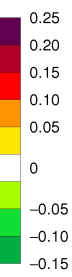

No. natural

stands

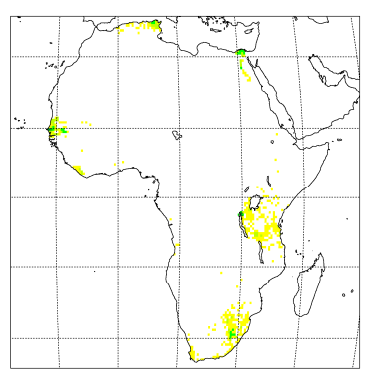

Fig. A3. (A) Cropland fractions for the time periods 1961-1970, 1971-1980 and 1981-1990, derived from Ramankutty and Foley (1999).

Green areas represent cropland abandonment. (B) Effect of cropland abandonment on the number of natural vegetation stands in a LPJGUESS simulation accounting for land cover change for the years 1970, 1980 and 1990. More than one natural stand is the result of previous years' cropland abandonment. 
Pasture fraction 1970

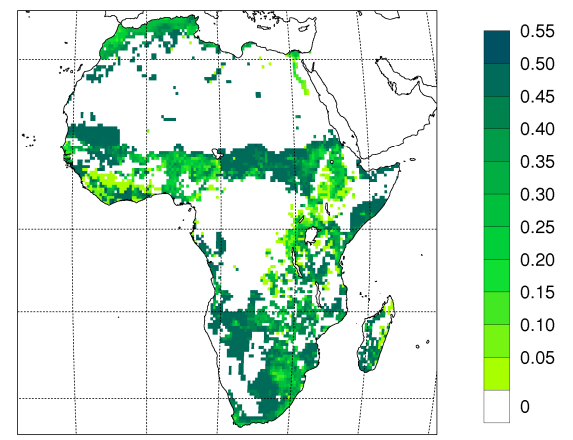

Fig. A4. Pasture fractions for 1970, derived from the HYDE database (Klein Goldewijk and Batjes, 1997).

1901

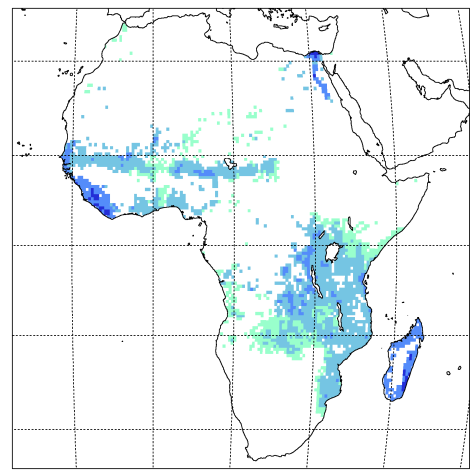

1995

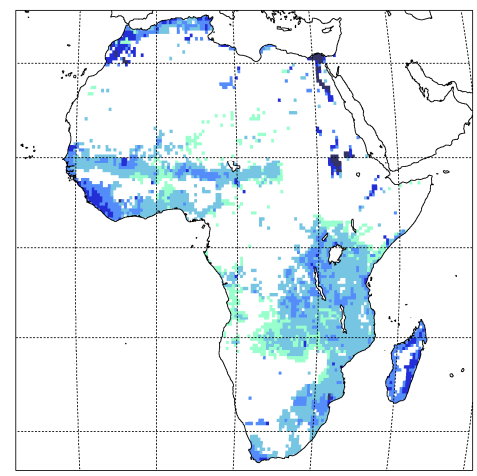

Irrigated cropland

fraction

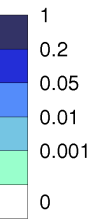

Fig. A5. Irrigated cropland fractions for the years 1901 (representing a state when only rice was assumed to be irrigated) and 1995 (from Döll and Siebert, 1999).

A

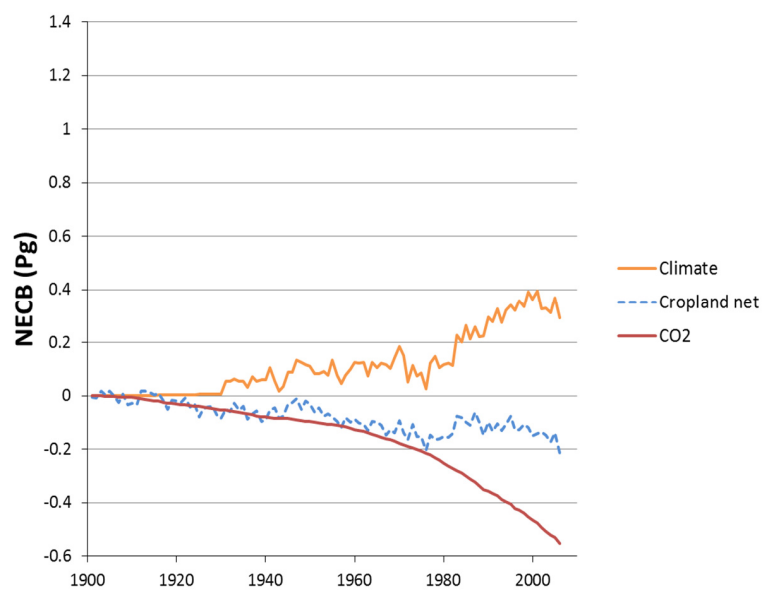

B

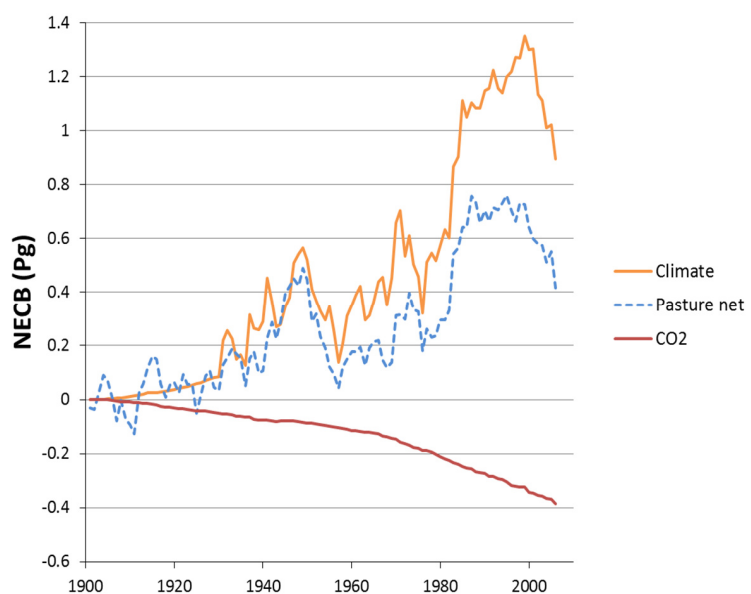

Fig. B1. Separate contributions of $\mathrm{CO}_{2}$ and climate change to the modelled 1901-2006 cumulative net ecosystem carbon balance (NECB) for cropland (A) and pasture (B) of the African continent, derived by comparing a simulation (S1, "net" in this figure) forced by historical $\mathrm{CO}_{2}$, climate and land use with separate simulations where either $\mathrm{CO}_{2}$ or climate was kept at the spin-up levels throughout the simulation period. Positive values represent a flux to the atmosphere. 
A
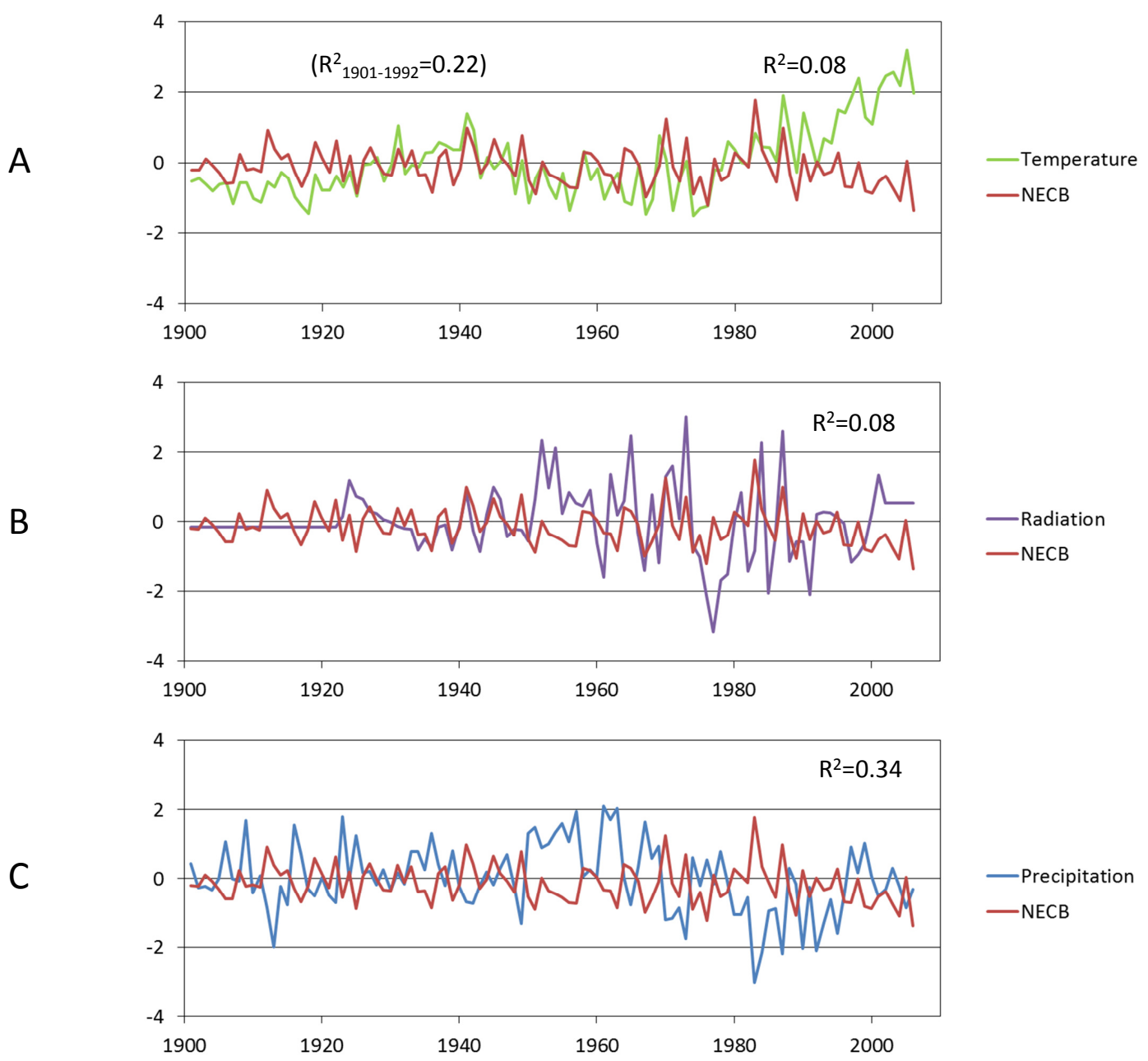

Fig. B2. Time series of standardised anomalies for simulated NECB for the African continent and (A) temperature, (B) radiation (\% sunshine) and (C) precipitation and associated correlation coefficients. For temperature, the correlation coefficient for a shorter period (1901-1992) is shown in brackets.

Acknowledgements. This study was funded by the Foundation for Strategic Environmental Research (Mistra) under the Mistra-SWECIA programme and by the Formas Strong Research Environment Land Use Today and Tomorrow. The study is a contribution to the European Union Seventh Framework Programme project ClimAfrica (FP7-ENV-2009-1, 244240) and to the strategic research areas Modelling the Regional and Global Earth System (MERGE), Biodiversity and Ecosystem Services in a Changing Climate (BECC) and the Lund Centre for Carbon Cycle and Climate Interactions (LUCCI). We thank J. Ardö for help in processing the NDVI data.

Edited by: N. de Noblet

\section{References}

Ahlström, A., Miller, P. A., and Smith, B.: Too early to infer a global NPP decline since 2000, Geophys. Res. Lett., 39, L15403, doi:10.1029/2012GL052336, 2012a.

Ahlström, A., Schurgers, G., Arneth, A., and Smith, B.: Robustness and uncertainty in terrestrial ecosystem carbon response to CMIP5 climate change projections, Environ. Res. Lett., 7, 0440082012b, doi:10.1088/1748-9326/7/4/044008, 2012b.

Ainsworth, E. A. and Long, S. P.: What have we learned from 15 years of free-air $\mathrm{CO}_{2}$ enrichment (FACE)? A meta-analytic review of the responses of photosynthesis, canopy properties and plant production to rising $\mathrm{CO}_{2}$, New Phytol., 165, 351-371, 2005.

Arneth, A., Sitch, S., Bondeau, A., Butterbach-Bahl, K., Foster, P., Gedney, N., de Noblet-Ducoudré, N., Prentice, I. C., Sanderson, M., Thonicke, K., Wania, R., and Zaehle, S.: From biota to chemistry and climate: towards a comprehensive description of trace gas exchange between the biosphere and atmosphere, Biogeosciences, 7, 121-149, doi:10.5194/bg-7-121-2010, 2010a. 
Arneth, A., Harrison, S. P., Zaehle, S., Tsigaridis, K., Menon, S., Bartlein, P. J., Feichter, J., Korhola, A., Kulmala, M., O’Donnell, D., Schurgers, G., Sorvari, S., and Vesala, T.: Terrestrial biogeochemical feedbacks in the climate system, Nat. Geosci., 3, 525532, doi:10.1038/ngeo905, 2010b.

Arora, V. K. and Montenegro, A.: Small temperature benefits provided by realistic afforestation efforts, Nat. Geosci., 4, 514-518, doi:10.1038/ngeo1182, 2011.

Berg, A., Sultan, B., and de Noblet-Ducoudré, N.: Including tropical croplands in a terrestrial biosphere model: application to West Africa, Climatic Change, 104, 755-782, doi:10.1007/s10584010-9874-x, 2011.

Bombelli, A., Henry, M., Castaldi, S., Adu-Bredu, S., Arneth, A., de Grandcourt, A., Grieco, E., Kutsch, W. L., Lehsten, V., Rasile, A., Reichstein, M., Tansey, K., Weber, U., and Valentini, R.: An outlook on the Sub-Saharan Africa carbon balance, Biogeosciences, 6, 2193-2205, doi:10.5194/bg-6-2193-2009, 2009.

Bondeau, A., Smith, P. C., Zaehle, S., Schaphoff, S., Lucht, W., Cramer, W., Gerten, D., Lotze-Campen, H., Müller, C., Reichstein, M., and Smith, B.: Modelling the role of agriculture for the 20th century global terrestrial carbon balance, Global Change Biol., 13, 679-706, doi:10.1111/j.13652486.2006.01305.x, 2007.

Brovkin, V., Sitch, S., von Bloh, W., Claussen, M., Bauer, E., and Cramer, W.: Role of land cover changes for atmospheric $\mathrm{CO}_{2}$ increase and climate change during the last 150 years, Global Change Biol. 10, 1253-1266, doi:10.1111/j.13652486.2004.00812.x, 2004.

Ciais, P., Piao, S.-L., Cadule, P., Friedlingstein, P., and Chédin, A.: Variability and recent trends in the African terrestrial carbon balance, Biogeosciences, 6, 1935-1948, doi:10.5194/bg-6-19352009, 2009.

Ciais, P., Bombelli, A., Williams, M., Piao, S. L., Chave, J., Ryan, C. M., Henry, M., Brender, P., and Valentini, R.: The carbon balance of Africa: synthesis of recent research studies, Philos. T. Roy. Soc. A, 369, 2038-2057, doi:10.1098/rsta.2010.0328, 2011.

DeFries, R. S., Houghton, R. A., Hansen, M. C., Field, C. B., Skole, D., and Townshend, J.: Carbon emissions from tropical deforestation and regrowth based on satellite observations for the 1980s and 1990s, P. Natl. Acad. Sci., 99, 14256-14261, doi:10.1073/pnas.182560099, 2002.

de Noblet-Ducoudré, N., Gervois, S., Ciais, P., Viovy, N., Brisson, N., Seguin, B., and Perrier, A.: Coupling the Soil-VegetationAtmosphere-Transfer Scheme ORCHIDEE to the agronomy model STICS to study the influence of croplands on the European carbon and water budgets, Agronomie, 24, 397-407, doi:10.1051/agro:2004038, 2004.

Doherty, R. M., Sitch, S., Smith, B., Lewis, S. L., and Thornton, P. K.: Implications of future climate and atmospheric $\mathrm{CO}_{2}$ content for regional biogeochemistry, biogeography and ecosystem across East Africa, Global Change Biol., 16, 617-640, doi:10.1111/j.1365-2486.2009.01997.x, 2010.

Döll, P. and Siebert, S.: A digital global map of irrigated areasdocumentation, University of Kassel, Kassel, 1999.

Easterling, W. E., Aggarwal, P. K., Batima, P., Brander, K. M., Erda, L., Howden, S. M., Kirilenko, A., Morton, J., Soussana, J.-F., Schmidhuber, J., and Tubiello, F. N.: Food, fibre and forest products, in: Climate Change 2007: Impacts, Adaptation and Vulnerability, Contribution of Working Group II to the Fourth
Assessment Report of the Intergovernmental Panel on Climate Change, edited by: Parry, M. L., Canziani, O. F., Palutikof, J. P., van der Linden, P. J., and Hanson, C. E., Cambridge University Press, Cambridge, UK, 273-313, 2007.

Evans, L. T.: Adapting and improving crops: the endless task, Philos. T. Roy. Soc. B, 352, 901-906, doi:10.1098/rstb.1997.0069, 1997.

Foley, J. A., DeFries, R., Asner, G. P., Barford, C., Bonan, G., Carpenter, S. R., Chapin, F. S., Coe, M. T., Daily, G. C., Gibbs, H. K., Helkowski, J. H., Holloway, T., Howard, E. A., Kucharik, C. J., Monfreda, C., Patz, J. A., Prentice, I. C., Ramankutty, N., and Snyder, P. K.: Global consequences of land use, Science, 309, 570-574, doi:10.1126/science.1111772, 2005.

Friend, A. D., Arneth, A., Kiang, N. Y., Lomass, M., Ogée, J., Rödenbeck, C., Running, S. W., Santaren, J.-D., Sitch, S., Viovy, N., Woodward, F. I., and Zaehle, S.: FLUXNET and modelling the global carbon cycle, Global Change Biol., 13, 610-633, doi:10.1111/j.1365-2486.2006.01223.x, 2007.

Gerten, D., Schaphoff, S., Haberlandt, U., Lucht, W., and Sitch, S.: Terrestrial vegetation and water balance-hydrological evaluation of a dynamic global vegetation model, J. Hydrol., 286, 249-270, doi:10.1016/j.jhydrol.2003.09.029, 2004.

Gervois, S., de Noblet-Ducoudré, N., Viovy, N., and Ciais, P.: Including croplands in a global biosphere model: methodology and evaluation at specific sites, Earth Interact., 8, 1-25, 2004.

Hall, P.: The poor quality of official socio-economic statistics relating to the rural tropical world: with special reference to south India, Mod. Asian Stud., 18, 491-514, 1984.

Hansen, M. C., Defries, R. S., Townshend, J. R. G., and Sohlberg, R.: Global land cover classification at $1 \mathrm{~km}$ spatial resolution using a classification tree approach, Int. J. Remote Sens., 21, 13311364, 2000.

Hély, C., Bremond, L., Alleaume, S., Smith, B., Sykes, M. T., and Guiot, J.: Sensitivity of African biomes to changes in the precipitation regime, Global Ecol. Biogeogr., 15, 258-270, doi:10.1111/j.1466-822x.2006.00235.x, 2006.

Heywood, V. H. (Ed.): Global biodiversity assessment, United nations environment programme, Cambridge University Press, Cambridge, 1995.

Hickler, T., Smith, B., Sykes, M. T., Davis, M. B., Sugita, S., and Walker, K.: Using a generalized vegetation model to simulate vegetation dynamics in the western Great Lakes region, USA, under alternative disturbance regimes, Ecology, 85, 519-530, 2004.

Hickler, T., Eklundh, L., Seaquist, J. W., Smith, B., Ardö, J., Olsson, L., Sykes, M. T., and Sjöström, M.: Precipitation controls Sahel greening trend, Geophys. Res. Lett., 32, L21415, doi:10.1029/2005GL024370, 2005.

Hickler, T., Prentice, I. C., Smith, B., Sykes, M. T., and Zaehle, S.: Implementing plant hydraulic architecture within the LPJ Dynamic Global Vegetation Model, Global Ecol. Biogeogr., 15, 567-577, doi:10.1111/j.1466-8238.2006.00254.x, 2006.

Hickler, T., Vohland, K., Feehan, J., Miller, P. A., Smith, B., Costa, L., Giesecke, T., Fronzek, S., Carter, T. R., Cramer, W., Kühn, I., and Sykes, M. T.: Projecting the future distribution of European potential natural vegetation zones with a generalized, tree species-based dynamic vegetation model, Global Ecol. Biogeogr., 21, 50-63, doi:10.1111/j.1466-8238.2010.00613.x, 2012. 
Hidy, D., Barcza, Z., Haszpra, L., Churkina, G., Pinter, K., and Nagy, Z.: Development of the Biome-BGC model for simulation of managed herbaceous ecosystems, Ecol. Model., 226, 99-119, doi:10.1016/j.ecolmodel.2011.11.008, 2012.

Holben, B. N.: Characteristics of maximum-value composite images from temporal AVHRR data, Int. J. Remote Sens., 7, 14171437, doi:10.1080/01431168608948945, 1986.

Houghton, R. A.: Revised estimates of the annual net flux of carbon to the atmosphere from changes in land use and land management 1850-2000, Tellus B, 55, 378-390, doi:10.1034/j.16000889.2003.01450.x, 2003.

Houghton, R. A., Hobbie, J. E., Melillo, J. M., Moore, B., Peterson, B. J., Shaver, G. R., and Woodwell, G. M.: Changes in the carbon content of terrestrial biota and soils between 1860 and 1980: a net release of $\mathrm{CO}_{2}$ to the atmosphere, Ecol. Monogr., 53, 235-262, 1983.

IMAGE team: Implementation of the SRES scenarios: a comprehensive analysis of emissions, climate change and impacts in the 21st century, National institute for public health and the environment, CD-ROM publication 481508018, RIVM, Bilthoven, the Netherlands, 2001.

Jain, A. K. and Yang, X.: Modeling the effects of two different land cover change data sets on the carbon stocks of plants and soils in concert with $\mathrm{CO}_{2}$ and climate change, Global Biogeochem. Cy., 19, GB2015, doi:10.1029/2004GB002349, 2005.

Kaspersen, P. S., Fensholt, R., and Huber, S.: A spatiotemporal analysis of climatic drivers for observed changes in Sahelian vegetation productivity (1982-2007), Int. J. Geophys., 2011, 715321, doi:10.1155/2011/715321, 2011.

Klein Goldewijk, K. and Battjes, J. J.: A hundred year (1890-1990) database for integrated environmental assessments (HYDE, version 1.1), National institute of public health and the environment (RIVM), Bilthoven, the Netherlands, 1997.

Klein Goldewijk, L., Beusen, A., van Drecht, G., and de Vos, M.: The HYDE 3.1 spatially explicit database of human-induced global land use change over the past 12,000 years, Global Ecol. Biogeogr., 20, 73-86, doi:10.1111/j.1466-8238.2010.00587.x, 2011.

Kucharik, C. J. and Brye, K. R.: Integrated biosphere simulator (IBIS) yield and nitrate loss predictions for Wisconsin maize receiving varied amounts of nitrogen fertilizer, J. Environ. Qual., 32, 247-268, 2003.

Kucharik, C. J. and Twine, T. E.: Residue, respiration, and residuals: Evaluation of a dynamic agroecosystem model using eddy flux measurements and biometric data, Agr. Forest Meteorol., 146, 134-158, doi:10.1016/j.agrformet.2007.05.011, 2007.

Lal, R.: Carbon sequestration in dryland ecosystems of West Asia and North Africa, Land Degrad. Dev., 13, 45-59, doi:10.1002/ldr.477, 2002.

Leff, B., Ramankutty, N., and Foley, J. A.: Geographic distribution of major crops across the world, Global Biogeochem. Cy., 18, GB1009, doi:10.1029/2003GB002108, 2004.

Lehsten, V., Tansey, K., Balzter, H., Thonicke, K., Spessa, A., Weber, U., Smith, B., and Arneth, A.: Estimating carbon emissions from African wildfires, Biogeosciences, 6, 349-360, doi:10.5194/bg-6-349-2009, 2009.
Le Quéré, C., Raupach, M. R., Canadell, J. G., Marland, G., Bopp, L., Ciais, P., Conway, T. J., Doney, S. C., Feely, R. A., Foster, P., Friedlingstein, P., Gurney, K., Houghton, R. A., House, J. I., Huntingford, C., Levy, P. E., Lomas, M. R., Majkut, J., Metzl, N., Ometto, J. P., Peters, G. P., Prentice, I. C., Randerson, J. T., Running, S. W., Sarmiento, J. L., Schuster, U., Sitch, S., Takahashi, T., Viovy, N., van der Werf, G. R., and Woodward, F. I.: Trends in the sources and sinks of carbon dioxide, Nat. Geosci. 2, 831-836, doi:10.1038/ngeo689, 2009.

Lewis, S. L., Lopez-Gonzalez, G., Sonke, B., Affum-Baffoe, K., Baker, T. R., Ojo, L. O., Phillips, O. L., Reitsma, J. M., White, L., Comiskey, J. A., Djuikouo, K. M.-N., Ewango, C. E. N., Feldpausch, T. R., Hamilton, A. L., Gloor, M., Hart, T., Hladik, A., Lloyd, J., Lovett, J. C., Makana, J. R., Malhi, Y., Mbago, F. M., Ndangalasi, H. J., Peacock, J., Peh, K. S. H., Sheil, D., Sunderland, T. C. H., Swaine, M. D., Taplin, J., Taylor, D., Thomas, S. C., Votere, R., and Woll, H.: Increasing carbon storage in intact African tropical forests, Nature, 457, 1003-1006, doi:10.1038/nature07771, 2009.

Licker, R., Johnston, M., Foley, J. A., Barford, C., Kucharik, C. J., Monfreda, C., and Ramankutty, N.: Mind the gap: how do climate and agricultural management explain the yield gap of croplands around the world?, Global Ecol. Biogeogr., 19, 769-782, doi:10.1111/j.1466-8238.2010.00563.x, 2010.

Liu, J., Fritz, S., van Wesenbeeck, C. F. A., Fuchs, M., You, L., Obersteiner, M., and Yang, H.: A spatially explicit assessment of current and future hotspots of hunger in Sub-Saharan Africa in the context of global change, Global Planet. Change, 64, 222235, doi:10.1016/j.gloplacha.2008.09.007, 2008.

Lobell, D. B., Cassman, K. G., and Field, C. B.: Crop yield gaps: their importance, magnitudes and causes, Annu. Rev. Environ. Res., 34, 179-204, doi:10.1146/annurev.environ.041008.093740, 2009.

Long, S. P., Ainsworth, E. A., Leakey, A. D. B., Nösberger, J., and Ort, D. R.: Food for thought: lower-than-expected crop yield stimulation with rising $\mathrm{CO}_{2}$ concentrations, Science, 312, 1918 1921, doi:10.1126/science.1114722, 2006.

McGuire, A. D., Sitch, S., Clein, J. S., Dargaville, R., Esser, G., Foley, J., Heimann, M., Joos, F., Kaplan, J., Kicklighter, D. W., Meier, R. A., Melillo, J. M., Moore III, B., Prentice, I. C., Ramankutty, N., Reichenau, T., Schloss, A., Tian, H., Williams, L. J., and Wittenberg, U.: Carbon balance of the terrestrial biosphere in the twentieth century: Analyses of $\mathrm{CO}_{2}$, climate and land use effects with four process-based ecosystem models, Global Biogechem. Cy., 15, 183-206, doi:10.1029/2000GB001298, 2001.

Millennium Ecosystem Assessment: Ecosystems and Human Wellbeing: Synthesis, World Resources Institute, Island Press, Washington, D.C., 2005.

Mitchell, T. D. and Jones, P. D.: An improved method of constructing a database of monthly climate observations and associated high-resolution grids, Int. J. Climatol., 25, 693-712, doi:10.1002/joc.1181, 2005.

Morales, P., Sykes, M. T., Prentice, I. C., Smith, P., Smith, B., Bugmann, H., Zierl, B., Friedlingstein, P., Viovy, N., Sabaté, S., Sanchez, A., Pla, E., Gracia, C. A., Sitch, S., Arneth, A., and Ogee, J.: Comparing and evaluating process-based ecosystem model predictions of carbon and water fluxes in major European forest biomes, Global Change Biol., 11, 2211-2233, doi:10.1111/j.1365-2486.2005.01036.x, 2005. 
Müller, C., Eickhout, B., Zaehle, S., Bondeau, A., Cramer, W., and Lucht, W.: Effects of changes in $\mathrm{CO}_{2}$, climate, and land use on the carbon balance of the land biosphere during the 21st century, J. Geophys. Res.-Biogeo., 112, G02032, doi:10.1029/2006JG000388, 2007.

Müller, C., Bondeau, A., Popp, A., Waha, K., and Fader, M.: Climate change impacts on agricultural yields, Potsdam Institute for Climate Impact Research (PIK), Background note for the World Development Report 2010, Contribution to the World Development Report 2010: Development and Climate Change, The World Bank, Washington, D.C., 2009.

Müller, C., Cramer, W., Hare, W. L., and Lotze-Campen, H.: Climate change risks for African agriculture, P. Natl. Acad. Sci., 108, 4313-4315, doi:10.1073/pnas.1015078108, 2011.

Piao, S., Sitch, S., Ciais, P., Friedlingstein, P., Peylin, P., Wang, X., Ahlström, A., Anav, A., Canadell, J. G., Cong, N., Huntingford, C., Jung, M., Levis, S., Levy, P. E., Li, J., Lin, X., Lomas, M. R., Lu, M., Luo, Y., Ma, Y., Myneni, R. B., Poulter, B., Sun, Z., Wang, T., Viovy, N., Zaehle, S., and Zeng, N.: Evaluation of terrestrial carbon cycle models for their response to climate variabiity and and to $\mathrm{CO}_{2}$ trends, Global Change Biol., 19, $2117-$ 2132, doi:10.1111/gcb.12187, 2013.

Pingali, P. L. and Pandey, S.: Meeting world maize needs: technological opportunities and priorities for the public sector, in: CIMMYT 1999/2000 World maize facts and trends, Meeting world maize needs: technological opportunities and priorities for the public sector, edited by: Pingali, P. L., CIMMYT, Mexico, 1-24, 2001.

Pitman, A. J., de Noblet-Ducoudré, N., Cruz, F. T., Davin, E. L., Bonan, G. B., Brovkin, V., Claussen, M., Delire, C., Ganzeveld, L., Gayler, V., van den Hurk, B. J. J. M., Lawrence, P. J., van der Molen, M. K., Müller, C., Reick, C. H., Seneviratne, S. I., Strengers, B. J., and Voldoire, A.: Uncertainties in climate responses to past land cover change: First results from the LUCID intercomparison study, Geophys. Res. Lett., 36, L14814, doi:10.1029/2009GL039076, 2009.

Ramankutty, N. and Foley, J. A.: Estimating historical changes in global land cover: croplands from 1700 to 1992, Global Biogechem. Cy., 13, 997-1028, doi:10.1029/1999GB900046, 1999.

Roudier, P., Sultan, B., Quirion, P., and Berg, A.: The impact of future climate change on West African crop yields: what does the recent literature say?, Global Environ. Change, 21, 1073-1083, doi:10.1016/j.gloenvcha.2011.04.007, 2011.

Rowhani, P., Lobell, D. B., Linderman, M., and Ramankutty, N.: Climate variability and crop production in Tanzania, Agr. Forest Metereol., 151, 449-460, doi:10.1016/j.agrformet.2010.12.002, 2011.

Seaquist, J. W., Hickler, T., Eklundh, L., Ardö, J., and Heumann, B. W.: Disentangling the effects of climate and people on Sahel vegetation dynamics, Biogeosciences, 6, 469-477, doi:10.5194/bg6-469-2009, 2009.

Sellers, P. J.: Vegetation-canopy spectral reflectance and biophysical processes, in: Theory and applications of optical remote sensing, edited by: Asrar, G., Wiley, New York, 297-335, 1989.

Sitch, S., Smith, B., Prentice, I. C., Arneth, A., Bondeau, A., Cramer, W., Kaplan, J. O., Levis, S., Lucht, W., Sykes, M. T., Thonicke, K., and Venevsky, S.: Evaluation of ecosystem dynamics, plant geography and terrestrial carbon cycling in the
LPJ dynamic global vegetaion model, Global Change Biol., 9, 161-185, doi:10.1046/j.1365-2486.2003.00569.x, 2003.

Sitch, S., Huntingford, C., Gedney, N., Levy, P. E., Lomas, M., Piao, S. L., Betts, R., Ciais, P., Cox, P., Friedlingstein, P., Jones, C. D., Prentice, I. C., and Woodward, F. I.: Evaluation of the terrestrial carbon cycle, future plant geography and climate-carbon cycle feedbacks using five Dynamic Global Vegetation Models (DGVMs), Global Change Biol., 14, 1-25, doi:10.1111/j.13652486.2008.01626.x, 2008.

Smith, B., Prentice, C., and Sykes, M. T.: Representation of vegetation dynamics in the modelling of terrestrial ecosystems: comparing two contrasting approaches within European climate space, Global Ecol. Biogeogr., 10, 621-637, doi:10.1046/j.1466822X.2001.t01-1-00256.x, 2001.

Smith, B., Knorr, W., Widlowski, J.-L., Pinty, B., and Gobron, N.: Combining remote sensing data with process modelling to monitor boreal conifer forest carbon balances, Forest Ecol. Manage., 255, 3985-3994, doi:10.1016/j.foreco.2008.03.056, 2008.

Thonicke, K., Venevsky, S., Sitch, S., and Cramer, W. : The role of fire disturbance for global vegetation dynamics: coupling fire into a Dynamic Global Vegetation Model, Global Ecol. Biogeogr., 10, 661-678, doi:10.1046/j.1466-822X.2001.00175.x, 2001.

Tittonell, P., Vanlauwe, B., Corbeels, M., and Giller, K. E.: Yield gaps, nutient use efficiency and response to fertilizers by maize across heterogeneous smallholder farms of western Kenya, Plant Soil, 313, 19-37, doi:10.1007/s11104-008-9676-3, 2008.

Tubiello, F. N., Amthor, J. S., Boote, K. J., Donatelli, M., Easterling, W., Fischer, G., Gifford, R. M., Howden, M., Reilly, J., and Rosenzweig, C.: Crop response to elevated $\mathrm{CO}_{2}$ and world food supply: A comment on "Food for Thought..." by Long et al., Science, 312, 1918-1921, 2006, Eur. J. Agron., 26, 215-223, doi:10.1016/j.eja.2006.10.002, 2007.

Tucker, C. J., Pinzon, J. E., Brown, M. E., Slayback, D., Pak, E. W., Mahoney, R., Vermote, E., and Saleous, N. E.: An Extended AVHRR 8-km NDVI data set compatible with MODIS and SPOT vegetation NDVI data, Int. J. Remote Sens., 26, 4485-4498, doi:10.1080/01431160500168686, 2005.

Van den Hoof, C., Hanert, E., and Vidale, P. L.: Simulating dynamic crop growth with an adapted land surface model - JULESSUCROS: Model development and validation, Agr. Forest Meteorol., 151, 137-153, doi:10.1016/j.agrformet.2010.09.011, 2011.

Van der Werf, G. R., Randerson, J. T., Giglio, L., Gobron, N., and Dolman, A. J.: Climate controls on the variability of fires in the tropics and subtropics, Global Biogeochem. Cy., 22, GB3028, doi:10.1029/2007GB003122, 2008.

Waha, K., van Bussel, L. G. J., Müller, C., and Bondeau, A.: Climate-driven simulation of global crop sowing dates, Global Ecol. Biogeogr., 21, 247-259, doi:10.1111/j.14668238.2011.00678.x, 2012.

Waha, K., Müller, C., Bondeau, A., Dietrich, J. P., Kurukulasuriya, P., Heinke, J., and Lotze-Campen, H.: Adaptation to climate change through the choice of cropping system and sowing date in sub-Saharan Africa, Global Environ. Change, 23, 130-143, doi:10.1016/j.gloenvcha.2012.11.001, 2013. 
Weber, U., Jung, M., Reichstein, M., Beer, C., Braakhekke, M. C., Lehsten, V., Ghent, D., Kaduk, J., Viovy, N., Ciais, P., Gobron, N., and Rödenbeck, C.: The interannual variability of Africa's ecosystem productivity: a multi-model analysis, Biogeosciences, 6, 285-295, doi:10.5194/bg-6-285-2009, 2009.

Williams, C. A., Hanan, N. P., Neff, J. C., Scholes, R. J., Berry, J. A., Denning, A. S., and Baker, D. F.: Africa and the global carbon cycle, Carbon Balance Manage., 2, 3, doi:10.1186/1750-0680-23, 2007.

Wramneby, A., Smith, B., and Samuelsson, P.: Hotspots of vegetation-climate feedbacks under future greenhouse forcing in Europe, J. Geophys. Res., 115, D21119, doi:10.1029/2010JD014307, 2010.
You, L., Wood, S., and Wood-Sichra, U.: Generating plausible crop distribution maps for Sub-Saharan Africa using a spatially disaggregated data fusion and optimization approach, Agr. Syst., 99, 126-140, 2009.

Zaehle, S., Ciais, P., Friend, A. D., and Prieur, V.: Carbon benefits of anthropogenic reactive nitrogen offset by nitrous oxide emissions, Nat. Geosci., 4, 601-605, doi:10.1038/NGEO1207, 2011.

Ziervogel, G., Cartwright, A., Tas, A., Adejuwon, J., Zermoglio, F., Shale, M., and Smith, B.: Climate change and adaptation in African agriculture, Rep., Stockholm Environment Institute, Stockholm, 2008 